University of Rhode Island

DigitalCommons@URI

Open Access Dissertations

1970

\title{
The Modification of Hepatic Microsomal Drug Metabolism by Phenobarbital and D-Amphetamine
}

Robert Thomas Louis-Ferdinand

University of Rhode Island

Follow this and additional works at: https://digitalcommons.uri.edu/oa_diss

\section{Recommended Citation}

Louis-Ferdinand, Robert Thomas, "The Modification of Hepatic Microsomal Drug Metabolism by Phenobarbital and D-Amphetamine" (1970). Open Access Dissertations. Paper 155.

https://digitalcommons.uri.edu/oa_diss/155

This Dissertation is brought to you for free and open access by DigitalCommons@URI. It has been accepted for inclusion in Open Access Dissertations by an authorized administrator of DigitalCommons@URI. For more information, please contact digitalcommons-group@uri.edu. 
THE MODIFICATION OF HEPATIC MICROSOMAL DRUG METABOLISM BY PHENOBARBITAL AND D-AMPHETAMINE

BY

ROBERT THOMAS LOUIS-FERDINAND

A THESIS SUBMITTED IN PARTIAL FULFILLMENT OF THE REQU IREMENTS FOR THE DEGREE OF DOCTOR OF PHILOSOPHY

IN

PHARMACEUTICAL SCIENCES 
TITLE ABSTRACT:

MODIFICATION OF DRUG METABOLISM 
DOCTOR OF PHILOSOPHY THESIS

$\mathrm{OF}$

ROBERT THOMAS LOUIS-FERDINAND

Approved:

Thesis Committee:

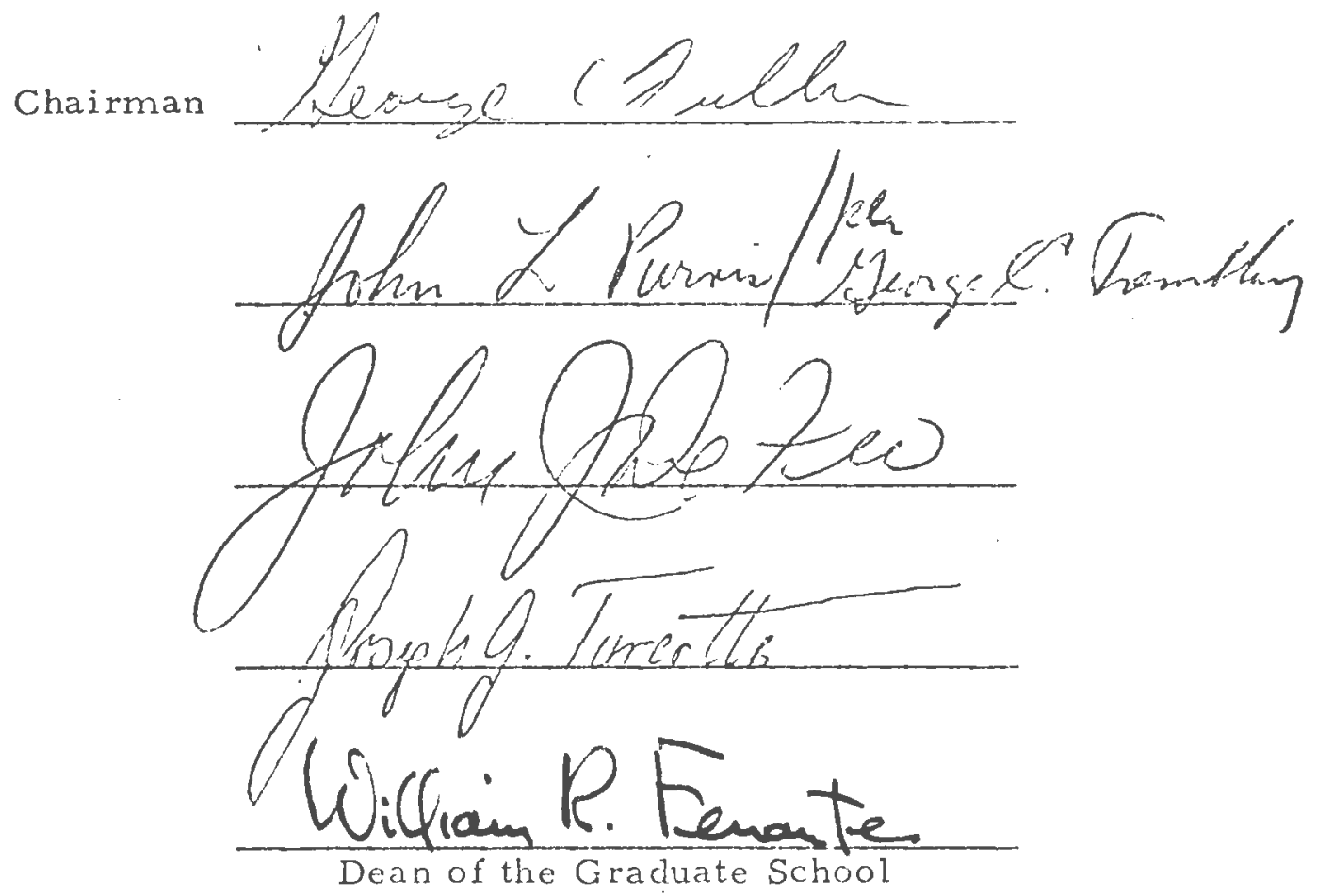

UNIVF.RSITY OF RHODE ISLAND 
DOCTOR OF PHILOSOPHY THESIS

OF

ROBERT THOMAS LOUIS-FERDINAND

Approved:

Thesis Committee:

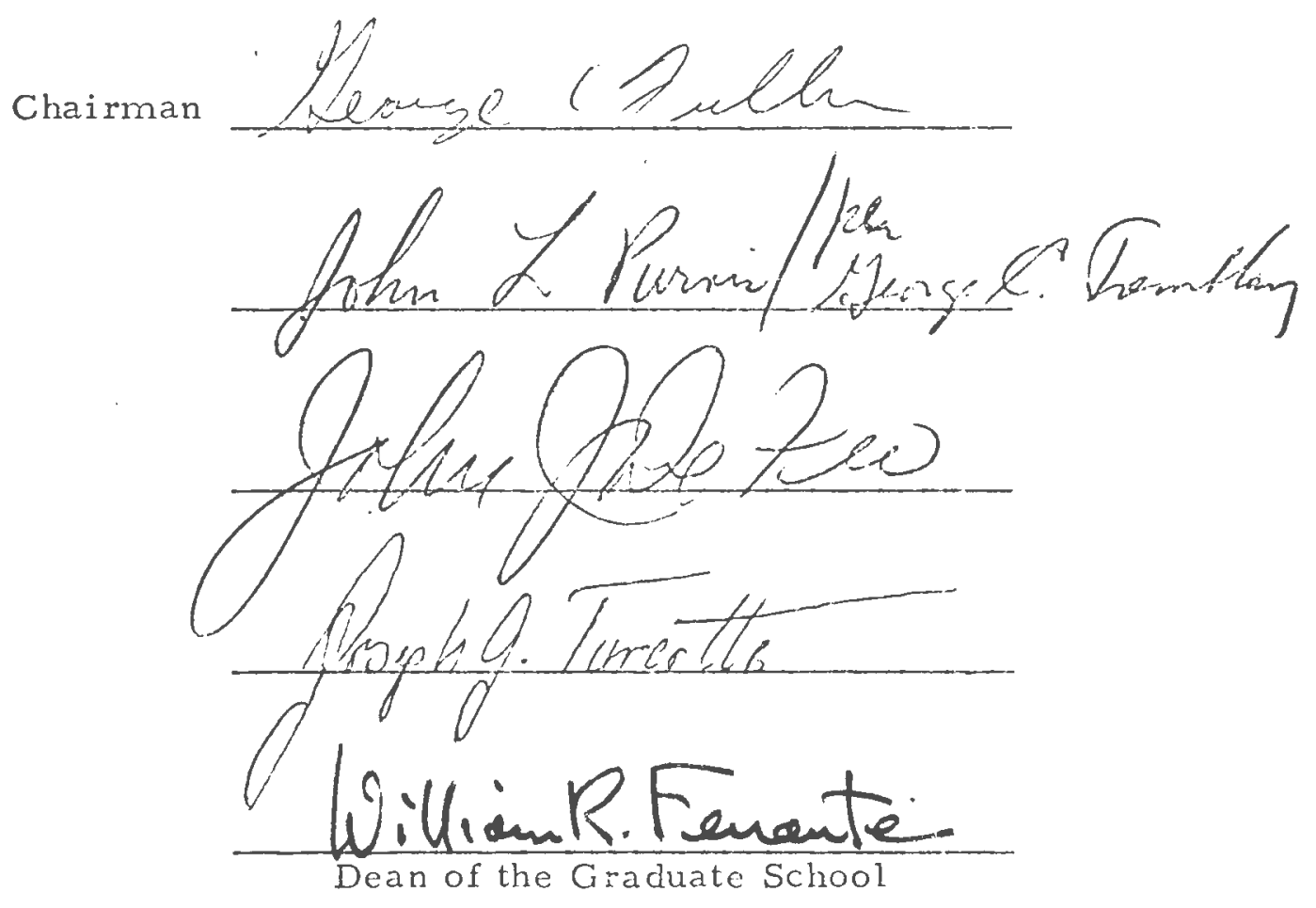




\begin{abstract}
Louis-Ferdinand, Robert Thomas, Ph. D. , University of Rhode Island August, 1969. The Modification of Hepatic Microsomal Drug Metabolism by Phenobarbital and Amphetamine. Major Professor: Dr. George C. Fuller.

This investigation was carried out to provide a mechanistic explanation for the modification of hepatic microsomal drug metabolism produced by amphetamine and phenobarbital. The influence of phenobarbital administration on the activity of microsomal ribonuclease during induction of drug-metabolizing enzymes, was determined. Administration of phenobarbital (100 mg/kg) for six days resulted in a significant $(\mathrm{P} \leq 0.05)$ increase in hepatic microsomal oxidative demethylation. Conversely, hepatic microsomal ribonuclease activity of phenobarbital-treated rats was significantly reduced to less than $5 \%$ of control values. When phenobarbital $(50 \mathrm{mg} / \mathrm{kg}$ ) was administered for 5 days ribonuclease activity was inhibited to about one-half of control values. Phenolpthalein $\beta$-glucuronidase activity of hepatic microsomal fractions obtained from phenobarbital treated animals was not significantly $(P>0.05)$ different from controls. Phenobarbital( $\operatorname{lx10^{-2}}$ Molar) did not inhibit ribonuclease activity following in vitro additions to the assay system. Time-response studies were conducted following the administration of a single dose of phenobarbital (100 mg/kg). Results of these studies indicated that microsomal p-chloro- $\mathrm{N}$-methylaniline (PCMA) demethylase stimulation and ribonuclease inhibition were temporaily related, except for a 24 hour lag in the PCMA demethylase response. Administration of phenobarbital ( $50 \mathrm{mg} / \mathrm{kg}$ twice-daily) produced significant inhibition of ribonuclease and stimulation of drug metabolism in liver microsomes of intact, adrenalectomized or hypophysectomized rats. Administration of 3-methylcholanthrene $(40 \mathrm{mg} / \mathrm{kg})$ to male rats resulted in a non-significant inhibition of ribonuclease activity while p-nitroanisole demethylation was stimulated three-fold. In vitro recombination experiments in which $105,000 \mathrm{xg}$ rat liver supernatants from control and treated animals were combined with microsomes
\end{abstract}




\section{ACKNOWLEDGEMENTS}

The author wishes to express his gratitude to his wife, Camille and his parents Mr. and Mrs. Joseph Louis-Ferdinand for their generosity, inspiration and understanding.

The guidance provided by Dr. George C. Fuller during the course of these studies is sincerely appreciated. The author wishes to convey his appreciation to his fellow students for the many helpful suggestions offered throughout this investigation.

This work was supported by a National Defense Education Act pre-doctoral fellowship and a Grant-In-Aid from the University of Rhode Island Research Committee. 
TABLE OF CONTENTS

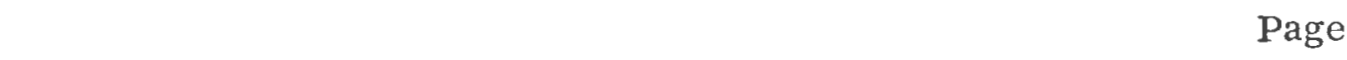

ABSTRACT............................. v

A CKNOWLEDGEMENTS..................... ii

TABLE OF CONTENTS. ......................... 1

LIST OF TABLES. ......................... 4

LIST OF FIGURES. ......................... 3

I. INTRODUCTION.................... 5

II. LITERATURE SURVEY.................... 7

A. Drug Metabolism.................... 7

B. Stilmulation of Drug Metabolism.......... 8

1. Effect of Inducing Agents on Protein Synthesis................... 8

2. Effect of Inducing Agents on phospholipid... 8

3. Effect of Inducing Agents on microsomal protein degradation............. 9

4. Other Post-Translational Mechanisms..... 10

5. Effect of Inducing Agents on RNA synthesis.................... 10

6. Evidence for Role of Ribonuclease........ 12

7. Physiological Control of Ribonuclease. activity.................. 16

C. Inhibition of Drug Metabolism............ 16

III. EXPERIMENTAL.................... 18

A. Animals......................... 18

B. Materials...................... 18

C. Preparation of Rat Liver Supernatant Fractions for Kinetic Studies................ 18

D. Preparation of Rat Liver Supernatant Fraction.... 18

E. Analytical Procedures.................. 19 
Page

1. Determination of Microsomal Demethylation of Aminopyrine.............. 19

2. Determination of P-Chloro-N-methylaniline Demethylation................ 19

3. Determination of Phenolpthalein- $\beta$-glucuronidase Activity............... 20

4. Determination of P-Nitroanisole Demethylase Activity.................... 21

5. Determination of Ribonuclease Activity.... 21

6. Estimation of Protein............. 22

F. Statistical Methods.................. 22

IV. RESULTS......................... 24

A. Inhibition of Ribonuclease During Induction by Phenobarbital.................. 24

B. In Vitro Recombination Studies.......... 30

C. Amphetamine Inhibition of P-Chloro-N-Methylaniline Demethylation............ 34

V. DISCUSSION......................

A. Inhibition of Microsomal Ribonuclease During Phenobarbital Induction............ 38

B. Competitive Inhibition by D-Amphetamine of Oxidative Demethylation........... 40

VI. CONCLUSIONS AND SUMMARY............. 42

VII. REFERENCES........................ 44

VIII. VITA............................. 54 


\section{LIST OF TABLES}

1 Inhibition of Hepatic Ribonuclease During Induction of Microsomal Aminopyrine Demethylase by Pheno-

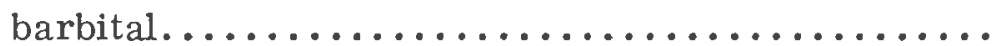

2 Inhibition of Ribonuclease During Phenobarbital Induction of Hepatic Microsomal Drug-Metabolism in Intact, Adrenalectomized and Hypophysectomized Male Rats..

3 Phenolpthalein- $\beta$-Glucuronidase Activity of Microsomal Fractions Obtained from Livers of Normal and Phenobarbital-Treated Rats..................

4 Comparison of Effect of Inchuction by 3-Methylcholanthrene on Hepatic Microsomal P-Nitroanisole Demethylase Activity and Ribonuclease.................

$5 \quad$ In Vitro Inhibition of Microsomal Ribonuclease by $105,000 \times \mathrm{g}$ Liver Supernatant Fraction of the Pheno-

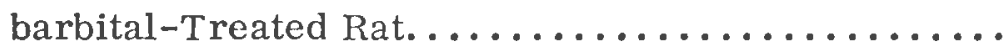

6 Ribonuclease Inlibition in the Presence of P-Chloromercuribenzoate by $105,000 \times$ g Supernatant Fraction Prepared from Livers of Phenobarbital-Treated Rats.

$7 \quad$ Kinetic Constants for D-Amphetamine Sulfate Inhibition of P-Chloro-N-Methylaniline Demethylation by Rat Liver $9000 \times \mathrm{g}$ Supernatant Fractions........... 


\section{LIST OF FIGURES}

Figure

Page

1 Effect of Phenobarbital on Rat Hepatic Ribonuclease During Stimulation of Microsomal Oxidative

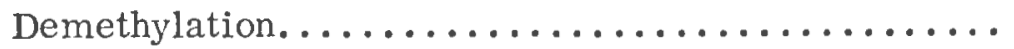

2 Lineweaver-Burk Plot of P-Chloro-N-Methylaniline Demethylation by Male and Female Rat Liver $9000 \mathrm{x} \mathrm{g}$ Supernatant in the Presence and Absence of 3 mMolar

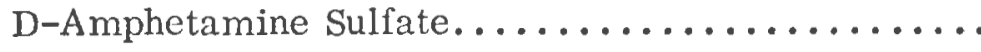




\section{INTRODUCTION}

Since the duration of action of many drugs is determined by the rate of hepatic drug-metabolism, (Conney, 1967) the pharmacological stimulation or inhibition of drug biotransformation is a mechanism responsible for many drug interactions. This thesis includes two independent investigations; one $\%$ designed to elucidate the mechanism of action of a drug which stimulates hepatic drug metabolism (Phenobarbital).

The phenomenon of enzyme induction (increased amount of enzyme) has long been a subject of interest to biochemists because of the key role this phenomenon plays in metabolism. However, the precise mechanisms involved in the regulation of many inducible enzymes are poorly understood. In addition to the apparent pharmacological significance of such a phenomenon, it is probable that investigations into the nature of the enhancement of drug-metabolizing systems can yield information relating to the general problem of the mechanism of substrate-induced synthesis of an organized multienzyme system.

After the first report of induction of hepatic microsomal drug metabolism (Brown et al., (1954) numerous investigators have demonstrated that the activity of microsomal enzymes can be marliedly influenced by the exposure of mammalian or non-mammalian organisms to a variety of foreign compounds (Conney, 1965). The enzyme inducers most frequently studied, phenobarbital ( $\mathrm{Pb}$ ) and 3-methylcholanthrene (MC) reportedly increase enzyme levels through enhanced de novo protein synthesis (Kato et al., 1965; Conney, 1956) following augmented DNAdependent RNA synthesis (Gelboin et al., 1967; Wilson et al., 1967). However, alternate explanations may be considered since microsomal protein may accumulate independently of enhanced protein synthesis (Barnhard, 1969) through stabilization of pre-existing protein (Kenny, 1967; Rechcigl, Jr., 1968). This argument is strengthened by the observation that $\mathrm{Pb}$ treatment will stabilize liver microsomal enzyme protein (Shuster and Jick, 1966) and phospholipid (Orrenius and Fricsson, 1966; Holtzman and Gillette, 1966). 
Messenger RNA turnover rate has been suggested as a potential control site in protein synthesis (Tomkins et al. , 1969; Lawford and Schachter, 1966) or hormone action (O'Malley, 1969). Conceivably, increased messenger RNA availability for translation into enzyme protein may result from increased DNA-dependent RNA synthesis and or reduced messenger RNA degradation. Accordingly it may be postulated that enzyme inducer's may increase liver microsomal protein content due to reduced protein or RNA degradation as well as via increased protein synthesis subsequent to enhanced RNA synthesis or both.

This investigation was undertaken to examine the role of microsomal ribonuclease in the induction of microsomal drug-metabolizing enzymes by $\mathrm{Pb}$ and $3 \mathrm{MC}$. Microsomal ribonuclease activity was examined during $\mathrm{Pb}$ induction in intact, adrenalectomized and hypophysectomized rats to determine whether intact adrenal or pituitary glands were required for suppression of ribonuclease activity. In vitro experiments were designed to detect the presence of inhibitors of ribonuclease activity in livers of Pb-treated rats. The second investigation described herein examines the mechanism of action of one of the known inhibitors of drug metabolism(amphetamine) (Lal, et al., 1970). The advisability of amphetamine administration to antagonize barbiturate depression may be questioned due to the recent finding of several investigators (Lal, et al., 1970; Weiss and Laties, 1964; Rushton and Steinberg, 1963). Amphetamine administration results in inhibition of hexobar-

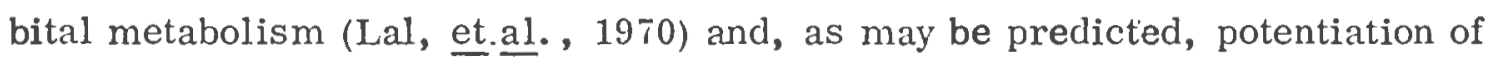
barbiturate activity (Weiss and Laties, 1964; Rushton and Steinberg, 1963). This section describes kinetic studies which have been performed using in vitro systems in order to determine a mechanistic basis for the potentiation of barbiturate action by administered amphetanine. 


\title{
II. LITERATURE SURVEY
}

\author{
Drug Metabolism
}

The duration and intensity of drug action is, for many agents inversely proportional to the rate at which the therapeutic agent may be removed from the body. Since many drugs must be metabolized to inactive metabolites prior to excretion, drug metabolism and its alteration has become an important therapeutic and pharmacologic consideration which has attracted a considerable amount of research attention. Numerous studies have shown that the majority of drugs are metabolized by few reactions, and that the enzyme systems which catalyze this metabolism are present in the endoplasmic reticulum of the liver (Claude, 1969).

The term microsome refers to the isolated form of the endoplasmic reticulum when this cytoplasmic constituent is obtained by differential centrifugation (Claude, 1969). Microsomal enzymes obtained from mammalian livers, catalyze a number of oxidations of which the reactions of oxidative drug metabolism (N-dealkylation, $\mathrm{O}-$ dealkylation, side chain oxidation, deamination and aromatic hydroxylation) are only a part (Greene, 1968). Early investigations have established that the enzymic oxidative metabolism of drugs is carried out by enzymes located in the microsomal fraction of the liver while the system which generates required NADPH can be found in the soluble fraction. Oxygen is also a necessary co-factor (Conney, 1967).

The requirement for both NADPH and oxygen is consistent with the postulate (Conney, 1967) that NADPH provides reducing equivalents for reduction of cytochrome $\mathrm{P}-450$ in liver microsomes. The reduced $\mathrm{P}-450$ is thought to form an "active oxygen" complex and the oxygen in the complex is then transferred to the drug substrate (Conney, 1967). 
Stimulation of Drug Metabolism

Effect of Inducing Agents on Protein Synthesis.

An inducing agent may be defined as a compound which enhances enzyme activity by increasing the concentration of enzyme protein.(Conney, 1967). Considerable evidence exists to support the hypothesis that enhancement of drug-metabolizing enzyme(DME) activity by phenobarbital(Pb) or 3-methylcholanthrene(MC) is mediated through stimulation of protein synthesis. Administration of $\mathrm{Pb}$ stimulates amino acid incorporation into liver microsomal protein in vivo (Kato, et al., 1965) and in vitro(Jondorf et al., 1966; Kato, et al. , 1966). The stimulation of amino acid incorporation and increase in microsomal enzyme activity following $\mathrm{MC}$ or $\mathrm{Pb}$ administration may be prevented by administration of actinomycin-D (Gelboin and Blackburn, 1964; Orrenius, 1964) an inhibitor of transcription (Reich, et al.,1961). The administration of inhibitors of translation such as ethionine(Conney, 1960) or puromycin(Conney, 1963) will also prevent the induction of $\mathrm{DME}$ by either $\mathrm{Pb}$ or $\mathrm{MC}$. Effect of Inducing Agents on Phopholipid.

The importance of suppressed degradation in increasing the levels of microsomal protein and phospholipid during $\mathrm{Pb}$ induction is controversial. $\mathrm{Pb}$ treatment is reported to stimulate the rate of incorporation of inorganic phosphate into microsomal phospholipid(Ernster and Orrenius, 1965; Orrenius et al.,1965). These results may be an indication of increased synthesis of phospholipids which accumulate in livers of $\mathrm{Pb}$-treated rats(Ernster and Orrenius, 1965). Holtzman and Gillette(1966) have demonstrated, however, that increased liver microsomal phospholipid in $\mathrm{Pb}$-treated rats results from inhibition of phospholipid degradation. Stein and Stein (1969) have arrived at similar conclusions after obscrving that $\mathrm{Pb}$ treatment results in the inhibition of acylphosphohydrolase (EC. 3.6.1.7) activity without stimulation of choline or ethanolamine incorporation into microsomal phospholipid. 
Tsukada and Lieberman (1965) suggest that microsomal phospholipid may stabilize polyribosomes sine phospholipase (EC. 3.1.1.4) treatment of polyribosomes restlts in inhibition of in vitro amino acid incorporation and marked polyribosomal disaggregation.

Effect of Inducing Agents on Microsomal Protein Degradation.

It has been postulated that the accumulation of liver microsomal protein following $\mathrm{Pb}$ treatment results from both a decreased rate of breakdown and an increased rate of synthesis. In support of this hypothesis Shuster and Jick (1966) demonstrated that $\mathrm{Pb}$ treatment reduces the rate of loss of incorporated tritiated leucine radioactivity from microsomal protein, to one-half that observed in controls. In addition, no loss of radioactivity from purified pre-labeled mouse liver NADPH Cytochrome c reductase (EC. 1.6.99.1) was observed following $\mathrm{Pb}$ induction (Jick and Shuster, 1966) suggesting a complete lack of degradation of the enzymes. Enzyme stabilization in the presence of cycloheximide inhibited protein synthesis has been reported by Kenny (1967). Loss of radioactivity from tyrosine-transaminase (EC. 2.6.1.5) occurs at a slower rate in cycloheximide-treated rats relative to untreated controls.

These findings are in contrast with those of Holtzman (1969) Schimke et al. , (1968) and Arias et al. , (1969) who have failed to demonstrate stabilization of microsomal protein by $\mathrm{Pb}$ in experiments utilizing ${ }^{14} \mathrm{C}$-guanidino-arginine, a non-reutilized amino acid. Shinke and collaborators compared the effect of $\mathrm{Pb}$ on microsomal isotope retention using ${ }^{14} \mathrm{C}$-guanidino-arginine or tritiated leucine as labels. They were able to demonstrate decreased release of label when leucine was used to pre-label microsomal protein, following $\mathrm{Pb}$ treatment. However, when ${ }^{14}$ C-guanidino-arginine was used no evidence of membrane protein stabilization by $\mathrm{Pb}$ could be demonstrated. The retention of ${ }^{3} \mathrm{H}$-leucine was attributed to an increased degree of isotope reutilization in the $\mathrm{Pb}$ treated animal. However, T. Omura at a recent meeting of the International Symposium 
on microsomes and drug oxidations, at Tubingen; as reported by Schenkman (1970) described studies indicating that ${ }^{14} \mathrm{C}$-guanidinoarginine-labeled microsomal protein degradation is inhibited by $\mathrm{Pb}$.

Thus, it is evident that the precise role of microsomal protein degradation in the mediation of $\mathrm{Pb}$ induction of $\mathrm{DME}$ remains unclear. Other Post-Translational Mechanisms.

Evidence exists to support a hypothesis that post-translational controls are operative during induction of microsomal DME systems. Reduction of levels of any rate-limiting component during induction will interfere with the enhancement of synthesis of metabolically active protein. 8 -Aminolevulinic acid synthetase induction by $\mathrm{Pb}$ was demonstrated by Marver (1969) who suggested this as a mcans of providing the additional heme required for increased synthesis of microsomal cytochromes. Administration of heme inhibits $\mathrm{Pb}$ induction of $\boldsymbol{\delta}$-aminolevulinic acid synthethase and DME activity and interferes with development of tolerance to hexobarbital (Narver, 1969). 3-Amino-1, 2,4-triazole inhibits rat hepatic $\delta$-aminolevulinic acid dehydratase (EC. 4.2.1.24) which catalyzes the second step involved in heme biosynthesis (Baron and Tephly, 1969). These authors demonstrated that 3-amino-1,2,4triazole inhibited $\mathrm{Pb}$ induction of cytochrome $\mathrm{P}-450$ and inhibited $\mathrm{Pb}$ stimulation of ethylmorphine, or 3-methyl, 4-monoethylaminobenzene metabolism (Baron and Tephly, 1969). However, no effect was observed on $\mathrm{Pb}$ stimulation of NADPH-cytochrome $c$ reductase activity in animals pretreated with 3-amino1,2,4-triazole (Baron and Tephly, 1969). While these data suggest that posttranslational control of $\mathrm{Pb}$ induction may exist, the possibility that these inhibitors may interfere with other limiting factors required for induction of DME, has not been excluded at this time.

Effect of Inducing Agents on RNA Synthesis.

The stimulation of hepatic protein synthesis by $\mathrm{Pb}$ or $\mathrm{MC}$ is postulated to involve enhancement of DNA-directed RNA synthesis. Administration of $100 \mathrm{mg} / \mathrm{kg}$ of either $\mathrm{Pb}$ or MC stimulates nuclcar RNA polymerase (as determined 
by incorporation of radioactive cytidine triphosphate into RNA) of isolated rat liver nuclei within 3-20 hours (Wilson, et a‥, 1967; Gelboin et al. , 1967; Nebert and Gelboin, 1969). MC stimulation of RNA polymerase (EC. 2.7.7.6) of isolated rat liver nuclei is consistent with reported stimulation of orotic acid- ${ }^{14} \mathrm{C}$ uptake into nuclear RNA 3 hours after injection of $\mathrm{MC}$ (Leob and Gelboin, 1964). Bresnick and Mossc (1969) have demonstrated that MC administration results in increased template activity of nuclear chromatin. In these studies RNA synthesis was catalyzed by purificd Micrococcus lysodeicticus RNA polymerase. Furthermore, nearest-neighbor frequency analyses of newly synthesized RNA indicate that this RNA is different from RNA synthesized from control preparations (Bresnick and Madix, 1969; Bresnick et al., 1969). As previously mentioned, the administration of actinomycin-D prevents the stimulation of benzpyrene hydroxylase activity by MC (Gelboin and Blackburn, 1964). These data indicate that MC induces liver DME through genomic activation, resulting in increased DNA-dependent RNA synthesis followed by enhanced synthesis of DME.

Different mechanisms may be involved during $\mathrm{Pb}$ induction. Chromatin isolated from $\mathrm{Pb}$-treated rats directs synthesis of RNA with similar nearestneighbor frequencies to control preparations (Bresnick and Madix, 1969). Actinomycin-D in doses close to the $\mathrm{LD}_{50}$ (Philips et al., 1960) inhibits but does not completely prevent stimulation of enzyme activity produced by five doses of Pb (Ernster and Orrenius, 1965; Orrcnius and Ernster, 1964). Threefold increases in DME activity are produced by $\mathrm{Pb}$ when actinomycin-D is given simultaneously for 5 days as opposed to 4.2 fold increases in DME produced by $\mathrm{Pb}$ alone.

Administration of an RNA polymerase inhibitor which has been characterized by Wilson et al., (1967); Gelboin, (1966) viz., Ai.atoxin B , $_{1}$ does not inhibit $\mathrm{Pb}$ induction of DME (Kato, et al., (1969). These authors have also demonstrated that $\mathrm{Pb}$ will induce tolerance to hexobarbital in the presence of aflatoxin $B_{1}$. 
Thioacetamicle is a carcinogen which increases nuclear size Muramatsu and Busch, 1962) and produces marked (8-10 fold) increases in latent nuclear ribonuclease activity and reduces cytoplasmic RNA content (Villabos et al., 1964; 1965; Busch, 1965). Thioacetamide prevents the increascs in microsomal $\mathrm{N}$-demethylase and cytochrome P-450 content usually associated with $\mathrm{Pb}$ induction, however, thioacetamide has little effect on the enhancement of drug metabolism resulting from MC administration (Sladek and Mannering, 1969; Mannering et al., 1969).

Enhancement of RNA polymerase has been reported in $\mathrm{Pb}$ treated adrenalectomized rats but not $\mathrm{Pb}$ treated hypophysectomized rats (Nebert and Gelboin, 1969; Wilson et al., 1967). However, it is well-established that Pbstimulation of microsomal amino acid incorporation (Jondorf et al., 1966) and induction of DME by $\mathrm{Pb}$ is not abolished by hypophysectomy (Conney, 1961). Thus, in hypophysectomized rats, $\mathrm{Pb}$-stimulation of RNA polymerase does not appear to play a major role in the induction of DNE.

Evidence for Role of Ribonuclease.

Several investigators (Tomkins et al., 1969; Bresnick, 1967; O'Malley, 1969) have postulated that messenger RNA stabilization might be involved in enzyme induction. Control of RNA lifetime by RNase could conceivably operate as a key factor in control of protein synthesis (Barnard, 1969).

Distribution studies of rat liver ribonuclease (RNase) indicate that RNase is widely distributed among particulate and non-particulate subcellular fractions (De Duve, 1955; Rahman, 1967). Approximately 26-50 percent of total cellular RNase is found in rat liver microsomal and soluble fractions. Rat liver ribonuclease activity components may be characterized by pH optima as follows: pH 6.0 (RNase I), pH 7.8 (RNase II), (Roth, 1954) and, pH 9.5 (RNase III) (Rahman, 1967). Acid RNase (RNase I) is localized in the lysosomal fraction along with other acid hydrolases while alkaline RNase has a somewhat wider distribution and is potentially in close contact with RNA (Kraft et al., 1969). 
An inverse relationship between RNase activity and RNA synthesis has been suggested by the finding of several workers. Reduced incorporation of label into RNA occurs in the presence of increased RNase activity (Meisler and Tropp, 1969). These authors also demonstrated that stimulation of in vitro RNA synthesis by deoxycholate or ammonium sulfate was correlated with inhibition of nuclear RNase. Similarly, Wilson et al., (1967) demonstrated that in the presence of added RNase negligible RNA polymerase activity (determined by cytidine- ${ }^{3}$ H txiphosphate incorporation into RNA) is observed. Further, Sarkar (1969), using a system induced by pretreatment with Triamcinolone observed an inverse correlation between liver RNase activity and RNA content.

Increased RNase activity in vitro has been shown to inhibit ${ }^{14} \mathrm{C}$-leucine incorporation into rat liver microsomes (Stone and Joshi, 1962). Addition of RNase to bacterial cell-free protein synthesizing systems inhibits ${ }^{14} \mathrm{C}$-phenylalanine incorporation into ribosomal protein by $99 \%$ (Scheinbuks et al., 1969). Inhibition of in vitro protein synthesis by RNase appears to be due to increased degradation of messenger RNA followed by polysomal disaggregation. Barondes and Nirenberg (1962) and Igarashi (1969) have reported that added synthetic messenger can be rapidly degraded in cell-free protein synthesizing systems before significant polymerization of amino acids can be detected. Blobel and Potter (1966) have postulated that polysomal structure is highly sensitive to RNase since exposed interribosomal messenger RNA segments are more readily available for digestion by RNase than are protein-protected ribosomal RNA. Utsunomiya and Roth (1966) compared relativc stabilities of ribosomal and non-ribosomal RNA by determining the origin of acid-soluble RNA degradation products in incubation media containing non-ribosomal RNA and ${ }^{32}$ P-labeled ribosomes. These authors demonstrated that ribosomal RNA was not significantly degraded to acid soluble products by RNase associated with ribosomal particles.

Recerst findings of Schlacger et al. (1969) are in contrast with earlicr studies which suggested an inverse relationship between polyribosome stability 
and RNase activity. Schlacger and collaborators treated tumor cells with 2,3,5-tris (ethylene imino)-1,4-benzoquinone (trenimon) to induce RNase activity and were unable to demonstrate any reduction in stability of polysomes isolated from tumor cells as cellular RNase activity as increased. However, these authors failed to demonstrate that the polyribosomes isolated from treinimon-treated cells were actually capable of supporting protein synthesis or that RNase associated with polyribosomes isolated from teinimontreated cells actually contained increased RNase activities.

In vitro recombination studies comparing amino acid-incorporating activity of cell-free systems derived from rat or chicken livers have demonstrated that chicken liver cell sap contains markedly elevated levels of RNase activity (Siler and Fied, 1968). These studies have shown that incubation of rat liver microsomes with chicken cell sap results in marked inhibition of polyuridylic acid-directed phenylalanine incorporation related to increased degradation of polyuridylic acid. Conversely, incubation of chicken liver microsomes with rat liver cell sap results in amino acid incorporation which is equivalent to that observed in incubations of rat supernatant and rat microsomes. These findings are consistant with those of Roth (1962) who has reported that an endogenous RNase inhibitor which is found in livers of rats, mice and hamsters, is absent in chicken liver. It is reasonable to conclude that the diminished protein synthetic ability of chicken liver microsomes associated with increased RNase activity is a function of messenger RNA destruction. Thus, the presence of high RNase activity would be expected to decrease the response of an inducing agent which stimulates enzyme synthesis. It has been demonstrated that while nikethimide induction of rats produces tolerance to pentobarbital, nikethimide pretreatment of chickens docs not reduce the effect of subsequent pentobarbital treatment (Brazda et al., 1965). DDT reduces dieldrin storage in the rat but not in the chicken (Strect et al., 1966). These results are consistent with the concept that induction of DME is more difficult in the presence of marked increases in RNase activity. 
Modification of RNA Degradation During Enzyme Induction. Administration of ${ }^{14} \mathrm{C}$-indoleacetic acid to green pea stem segments results in iniliation of growth and increased labeling of RNA (Bedana and Galston, 1965). RNA fractions extracted from treated stem segments are more resistant to RNA degradation than those extracted from untreated control preparations. During cortisone induction an inverse relationship has been demonstrated (Barnabei and Ottolenghi, 1968) between activity of rat liver microsomal RNase and RNA polymerase. A similar inverse relationship between RNA polymerase and microsomal RNase after cortisone treatment has been reported (Terner et al., 1967). Sarkar et al., (1969) have demonstrated a reduction of rat liver acid (EC. 2.7.7.16) and alkaline RNase (EC. 2.7.7.17) activity during triamcinolone treatment which could be correlated with increases in aspartate and alanine aminotransferase activities.

Hormones have been shown to alter tissue RNase activity. Augmented RNA levels have been correlated with decreased adrenal RNase following corticotrophin administration to rats. This suppression of adrenal RNase activity could be correlated with increased amounts of RNase inhibitor (Imrie and Hutchison, 1965). Brewer ct al., (1969) reported two-fold increases in alkaline RNase in postmitochondrial supernatant fractions prepared from hypophysectomized rats. They also reported that administration of growth hormone resulted in the reduction of RNase activity to control levels.

The half-life of deoxythymidine kinase messenger RNA is doubled in regenerating rat liver compared to controls (Bresnick, et al., 1967). These authors postulate that hepatectomy results the elaboration of a substance which prolongs mRNA half-life by inactivating RNA catabolism. Inhibition of RNA degradation in regenerating liver may be attributable to increased amounts of endogenous RNase inhibitors which accumulate in regenerating rat liver (Russell and Snyder, 1969; Tsukada, 1969; Shortman, 1962).

Thus much experimental evidence suggest that RNA levels and protein 
synthesis are influenced by RNase activity. Altered RNA degradation appears to be part of the total cellular response to certain drugs and hormones as well as experimental procedures which result in or otherwise affect induction of enzyme protein.

Physiolorical Control of Ribonuclease Activity; Mechanisms.

Several potential control mechanisms have been implicated in the literature or otherwise indicated as physiological control mechanisms of RNA degradation. The more obvious among these are:

A) Compartmentation of enzyme (or subtrate) such as occurs with lysosomal concentration of acid RNase (Kraft, et al., 1969).

B) Endogenous inhibitors of RNase such as cations (Lamana and Mallette, 1949) polyamines (Busch, 1965) or protein RNase inhibitors (Gribnau et al., 1970; Roth, 1962; Shortman, 1961; 1962).

C) Steric inaccesibility ofRNA to degradation by RNase e.g. ribosomal RNA protection (Utsunomiya and Roth, 1966) (Castle and Singer, 1965).

D) Combination of hormone with RNA resulting in stabilization of hormone-RNA complex (Bedana and Galston, 1965) or prevention of ribosomal attachment to RNA resulting in enhancement of RNA degradation (Tomkins et al., 1969).

Inhibition of Drug Metabolism

The clinical administration of amphetamine in cases of barbiturate poisoning is based on the expected antagonism of barbiturate activity by this stimulant. However, recent findings that amphetamine will potentiate barbiturate activity in certain instances suggest that this practice may be illadvised.

Rushton and Steinberg (1963) have demonstrated that simultaneous administration of "amobarbitone and d-amphetamine resulted in potentiation of the effects of "amobarbitone" on rat motor activity. Weiss and Laties (1964) demonstrated that combinations of pentobarbital and amphetamine potentiated 
pentobarbital effects on dog behavioral activity. Such potentiation of barbiturate activity may be att ributable to amphetamine interference with barbiturate biotransformation. Reports of interference with drug metabolism involving amphotamine and methylphenidate (a related phenethylamine derivative) have appeared in the recent literature.

Methylpheniclate inhibits imipramine metabolism in mouse liver where imipramine hydroxylation predominates and in rat liver where demethylation is themajor route of imipramine biotransformation (Perel et al., 1969). Similarly, d-amphetamine metabolism which presumably involves p-hydroxylation (Axelrod, 1954) by perfused rat liver, is inhibited by desipramine (Dingel and Bass, 1969). Lal et al., (1970) have demonstrated that amphetamine inhibits mouse liver hexobarbital oxidase following in vivo administration or in vitro addition of amphetamine to incubation mixtures. These results appear to contrast with those of Kato et al., (1964); Kato and Chiesara (1962) and Kato and Vassanelli (1962) who failed to demonstrate any effect of amphetamine administration on the response of rats to subsequent administration of meprobamate or"phenobarbitone." However, Kato and collaborators pretreated rats with amphetamine 48 hours prior to testing while Lal and co-workers administered amphetamine 1 hour before testing.

Inhibition of drug-metabolism occurs competitively in the presence of alternative substrates of microsomal DME (Rubin et al., 1964). It is reasonable to expect that since amphetamine is para hydroxylated by the rat in vivo (Axelrod, 1954), amphetamine inhibition of drug metabolism may be attributed to competition by an alternative substrate. However, $d$-amphetamine is not metabolized by rat liver microsomes (Groppetti and Costa, 1965) or rat liver $10,000 \mathrm{xg}$ supernatant fractions (Dingel and Bass, 1969). These findings suggest that an investigation of the kinetics of amphetamine inhibition of drug metabolism by liver supernatant fraction may contribute to a better understanding of the mechanisms involved in similar drug-drug interactions. 


\section{EXPERIMENTAL}

\section{Animals}

Male and female Sprague-Dawley rats obtained from Charles River Breeding Laboratories (Wilmington, Mass.) weighing between $0.1-0.5 \mathrm{~kg}$ were used throughout the course of these studies. The rats were maintained on commercial laboratory chow and water ad libitum in a room with controlled temperature and alternating 12-hour periods of light and darkness. All drugs were administered via the intraperitoneal route. Adrenalectomies and Hypophyscctomies were performed by Charles River Breeding Laboratories. Materials

Analytical reagent grade chemicals or equivalent were used throughout these studies. Cofactors (NADP, glucose-6-phosphate, p-chloroaniline, pchloro-N-methylaniline, glucose-6-phosphate dehydrogenase (EC \#1.1.1.49) and highly polymerized yeast RNA) were obtained from Calbiochem. Los Angeles, Calif. and crystalline bovine serum albumin was obtained from Armour Laboratories. Drugs used were obtained from their respective manufacturers. Preparation of Rat Liver Supernatant Fractions For Kinetic Studics.

Female (250-300 $\mathrm{gm})$ and Male (325-348 gm) rats were decapitated. Livers were perfused with ice-cold $0.15 \mathrm{M} \mathrm{KCl}$ and were homogenized in 2 vol. of ice-cold $0.1 \mathrm{M}$ phosphate (pH7.4) buffer for $1 \mathrm{~min}$ in a coaxial homogenizer. The $9000 \mathrm{x}$ g supcrnatant fraction was obtained by centrifugation at $0^{\circ} \mathrm{C}(10,000$ rpm in an Model B-60 International Preparative Ultracentrifuge (I. E. C. ) \#874 rotor) for $30 \mathrm{~min}$.

Preparation of Rat Liver Supernatant Fractions.

Adult male rats werc fuillotined following overnight fast. Their livers were perfused in situ with ice-cold $0.25 \mathrm{~N}$ sucrose and were homogenized with a coaxial homogenizer at 1000 RPM for onc minute with 3-5 volumes of ice-cold $0.25 \mathrm{M}$ sucrose. Homogenates were centrifuged at $14,000 \mathrm{x}$ g for $15 \mathrm{~min}$ at 
$0^{\circ} \mathrm{C}$ in I. E. C. preparative ultracentrifuge and the resulting supernatant was centrifuged at $105,000 \mathrm{x}$ g for 2 hours at $0^{\circ} \mathrm{C}$. The $105,000 \mathrm{xg}$ pellet was rinsed and dispersed in $0.25 \mathrm{M}$ sucrose and stored at $-20^{\circ} \mathrm{C}$ until assayed. Analytical Procedures

Determination of Microsomal Demethylation of Aminopyrine.

Microsomal demethylation of aminopyrine was determined by assaying for formaldchyde formed as described by McMahon and Easton (1962). The incubation medium ( $5 \mathrm{ml}$ ) for aminopyrine demethylation contained aminopyrine

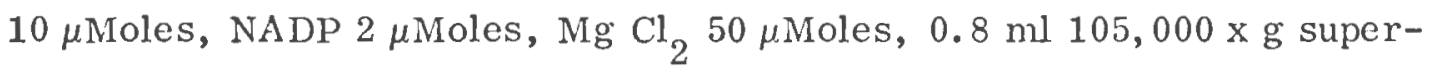
natant from control animals, $0.2 \mathrm{ml}$ microsomal suspension (approximately $6 \mathrm{mg}$ protein) and $1 \mathrm{ml} 0.1 \mathrm{M}$ phosphate buffer pH 7.4. Parallel incubation flasks containing $1.32 \mu$ Moles of formaldehyde (standard) in place of substrate and distilled water (blank) in place of substrate were carried through the entire procedure. Flasks were incubated in a Dubnoff shaker at $37^{\circ} \mathrm{C}$ under air for $30 \mathrm{~min}$. At the end of the incubation period flask contents were poured into centrifuge tubes. Four $\mathrm{ml}$ of $10 \%$ zinc chloride (prepared with $\mathrm{CO}_{2}$-frce water) were addled and the tubes were mixed. Two $\mathrm{ml}$ of a saturated solution of barium hydroxide were added and the samples were mixed again. The samples wcre centrifuged for approximately $10 \mathrm{~min}$ and $5.0 \mathrm{ml}$ aliquots of clear supernates were transferred to glass tubes containing $2.0 \mathrm{ml}$ of double-strength Nash reagent $(0.04 \mathrm{M}$ acetylacetone in $0.4 \mathrm{M}$ ammonium acetate-0.1 $\mathrm{M}$ acetic acid). The contents were mixed and the tubes were heated in a water bath at $60^{\circ} \mathrm{C}$ for $30 \mathrm{~min}$. Absorbance was determined on a Beckman DB-G grating spectrophotometer at $410 \mathrm{~m} \mu$, and the values were corrected for color of the blank. Amount of formaldehyde formed was determined by comparison with absorbance of standards.

Determination of P-Chloro-N-Methylaniline Demethylation.

Demethylation of p-chloro-N-methylaniline (PCNA) was determined by assaying for $\mathrm{p}$-chloroaniline formed according to the procedure of Kupfer 
and Bruggeman (1966) as modified by Fuller et al., (1969). Incubations were carried out at $37^{\circ} \mathrm{C}$ under air for $30 \mathrm{~min}$ in media which contained $3 \mu$ Moles PCMA, 1.6 $\mu$ Moles NADP, $16 \mu$ Moles glucose-6-phosphate, $30 \mu$ Moles $\mathrm{Mg} \mathrm{Cl}_{2}, 20 \mu$ Moles nicotinamide, $5 \mathrm{IU}$ glucose-6-phosphate dehydrogenase, $120 \mu$ Moles phosphate buffer (pH 7.4) and 14,00 x g rat liver supernatant $(2-4 \mathrm{mg})$ protein. The reaction was stopped by the addition of $3.0 \mathrm{ml} \mathrm{p}$-dimethylaminobenzaldehycle $\left(20 \mathrm{mg} / \mathrm{ml}_{1} \mathrm{~N} \mathrm{H}_{2} \mathrm{SO}_{4}\right.$ ) solution. Incubation flask contents were mixed and centrifuged at $8000 \mathrm{x} \mathrm{g}$ for $30 \mathrm{~min}$. Colors read on a Beckman DB-G grating spectrophotometer at $445 \mathrm{~m} \mu$ were corrected for color of blanks. Amount of $\mathrm{p}$-chloroaniline formed was determined by comparison with standards.

For kinetic studies PCMA demcthylation was determined as described above with the following modifications. Incubations were carried out at $37^{\circ} \mathrm{C}$ under air in media containing $0.2 \mathrm{ml} 9000 \mathrm{x}$ g supernatant protein $(6.6-7.4 \mathrm{mg}$ protein) equivalent to approximately $100 \mathrm{mg}$ liver; $1.6 \mu$ Moles NADP, $16 \mu$ Moles glucose-6-phosphate, $30 \mu$ Moles $\mathrm{MgCl}_{2}, 20 \mu$ Moles nicotinamide, $150 \mu$ Moles phosphate buffer (pH 7.4) and PCMA $(6,4,5,3$ or $1.5 \mu$ Moles) in a total volume of $2 \mathrm{ml}$. Six $\mu$ Moles d-amphetamine sulfate was used.

Determination of Phenolpthalein- $\underline{\beta}$-Glucuronidase Activity.

Phenolpthalein- $\beta$-glucuronidase activity associated with microsomal fractions was determined by assaying for phenolpthalein formed from phenolpthalein glucuronide according to the procedure of Talalay et al. (1946). Incubations were carried out in a dubnoff shaker for $15 \mathrm{~min}$ at $37^{\circ} \mathrm{C}$. Incubation media contained $5 \mu \mathrm{l}$ microsomal suspension $(0.2 \mathrm{mg}$ protein) $0.5 \mathrm{ml}$ phenolpthalein- $\beta$-glucuronide $(2 \mathrm{mg} / \mathrm{ml}$ in $0.2 \mathrm{M}$ acetate buffer (pH 5.2) solution, $0.5 \mathrm{ml}$ deionized water, $4.0 \mathrm{ml} 0.2 \mathrm{M} \mathrm{pH} 5.2$ acetate buffer. Parallel incubations containing $50 \mu \mathrm{g}$ phenolpthalein (standard) in place of substrate and distilled water (blank) in place of substrate were carried through the entire procedure. 
At the end of the incubation period $5.0 \mathrm{ml} 4 \mathrm{M}$ glycine (adjusted to $\mathrm{pH}$ 10.7 with $\mathrm{NaOH}$ ) was added to the flasks and the contents were centrifuged for 15 min in a clinical centrifuge. Absorbances read on a Beckman DB-G grating spectrophotometer at $545 \mathrm{~m} \mu$ were corrected for color of blanks. The amount of phenolpthalein formed was determined by comparison with the standard.

Determination of P-Nitroanisole Demethylase Activity.

P-Nitroanisole demethylase activity associated with microsomal fractions was determined by assaying for p-nitrophenol formed according to a modification of the procedure of Netter and Seidel (1964). Incubations were carried out at $37^{\circ} \mathrm{C}$ under air for $30 \mathrm{~min}$ in a medium containing $3 \mu$ Moles p-nitroanisole, $2 \mu$ Moles NADP, $20 \mu$ Moles glucose-6-phosphate, $80 \mu$ Moles nicotinamide, $120 \mu \mathrm{Moles} \mathrm{Mg} \mathrm{Cl}_{2}$, $5 \mathrm{U}$ glucose-6-phosphate dehydrogenase microsomal protein (2-3 mg) and $1 \mathrm{ml} 0.1$ molar phosphate (pH 7.9) buffer in a total volume of $3.9 \mathrm{ml}$.

At the end of the incubation period $10 \mathrm{ml}$ ice-cold acetone was added to the incubation flasks. One $\mathrm{ml} 0.5 \mathrm{M}$ glycine (adjusted to $\mathrm{pH} 9.5$ with $\mathrm{NaOH}$ ) was added. After centrifugation the supernatant was read against the tissue blank at $410 \mathrm{~m} \mu$ on a Beckman DB-G grating spectrophotometer. Amount of p-nitrophenol formed was determined by comparison with standard p-nitrophenol solutions.

Determination of Ribonuclease Activity.

Ribonuclease activity of microsomal fractions was determined by assaying for the acid-ethanol-soluble degradation products of highly polymerized RNA, according to a modification of the procedure of Tsukada (1969). Incubations were carried out at $37^{\circ} \mathrm{C}$ under air for $20 \mathrm{~min}$ in a medium containing $0.2 \mathrm{ml}$ $0.2 \mathrm{M}$ Tris- $\mathrm{HCl}$ buffer $\mathrm{pH} 7.6,1 \mathrm{mg}$ highly polymerized yeast RNA and microsomal protein $(0.5-1 \mathrm{mg})$. At the end of the incubation period $1.0 \mathrm{nl} 1 \mathrm{M} \mathrm{HCl}$ in $76 \%$ ethanol was added as a precipitant and the mixture was shaken thoroughly. 
The soluble fraction was separated by centrifugation at $10,000 \mathrm{RPM}$ at $0^{\circ} \mathrm{C}$ in the \#874 rotor of the I.E.C. preparative ultracentrifuge for $15 \mathrm{~min}$. The absorbance of $1 \mathrm{ml}$ of the clear supernatant after dilution with 2-5 $\mathrm{ml}$ distilled water was read at $260 \mathrm{~m} \mu$ vs distilled water using a Beckman DB-G grating spectrophotometer. Reading's obtained were corrected for absorbances of individual tissue and RNA blanks.

\section{Estimation of Protein}

Protein content was determined by the colorimetric procedure of Lowry et al., (1951) with minor modifications. An aliquot $(0.1 \mathrm{ml})$ of microsomal suspension was added to $15 \mathrm{ml}$ test tubes containing $10 \mathrm{ml}$ of $0.5 \mathrm{M}$ sodium hydroxide. The tubes were heated in a water bath until dissolution was complete. Standard solutions of crystalline bovine serum albumin and a blank consisting of $0.25 \mathrm{M}$ sucrose were carried through the entire procedure. When the tissue was dissolved a $0.5 \mathrm{ml}$ aliquot was removed and placed into a second tube containing $1 \mathrm{ml}$ of $0.5 \mathrm{M}$ sodium hydroxide solution. Five $\mathrm{ml}$ of reagent ' $\mathrm{A}$ ' (prepared by the addition of $1.0 \mathrm{ml} 1 \%$ cupric sulfate solution plus $1.0 \mathrm{ml}$ of $2.7 \%$ potassium tartrate to $100 \mathrm{ml}$ of $2 \%$ sodium carbonate solution) was added to each tube, mixed, and the tubes were allowed to stand at room temperature for $20 \mathrm{~min}$. At this time $0.5 \mathrm{ml}$ reagent ' $\mathrm{B}$ ' (prepared by diluting commercial Folin-phenol reagent with an equal volume of distilled water) was added to each sample. The samples were allowed to stand at room temperature for $40 \mathrm{~min}$ to develop color. Absorbance at $500 \mathrm{~m} \mu$ of the solutions was determined against the blank in a Beckman DB-G grating spectrophotometer.

\section{Statistical Methods}

The students' "t" test calculated on an Olivetti Underwood Programma 101 was used to test for differences between means throughout this study. The formula employed is as follows: 


$$
t=\frac{\bar{x}_{1}-\bar{x}_{2}}{s_{p} \sqrt{\left(1 / N_{1}\right)+\left(1 / N_{2}\right)}}
$$

where:

$$
\mathrm{s}_{\mathrm{p}}^{2}=\frac{\left(\mathrm{N}_{1}-1\right) \mathrm{S}_{1}^{2}+\left(\mathrm{N}_{2}-1\right) \mathrm{S}_{2}^{2}}{\mathrm{~N}_{1}+\mathrm{N}_{2}-2}
$$

$\mathrm{N}_{1}=$ Control sample size $\quad \mathrm{s}_{2}{ }^{2}=$ Treated sample variance

$\mathrm{N}_{2}=$ Treated sample size $\quad \overline{\mathrm{x}}_{1}=$ Control sample mean

$\mathrm{S}_{1}^{2}=$ Control sample variance $\quad \overline{\mathrm{X}}_{2}=$ Treated sample mean

The degrees of freedom were taken as $\mathrm{N}_{1}+\mathrm{N}_{2}-2$

The levels of P: were taken from Appendix 3 (Spiegel, 1961)

\section{Calculation of Kinetic Constants}

The data obtained from kinetic studies was statistically analyzed using an IBM linear regression computer program entitled 'Boing'. The formula used is as follows:

$$
\begin{aligned}
& Y=A_{0}+A_{i} X \\
& A_{0}=\frac{\left(\sum Y\right)\left(\sum X^{2}\right)-\left(\sum X\right)\left(\sum X Y\right)}{N \sum X^{2}-\left(\sum X\right)^{2}} \\
& A_{i}=\frac{N \Sigma X Y-\left(\sum X\right)\left(\sum Y\right)}{N \Sigma X^{2}-\left(\sum X\right)^{2}}
\end{aligned}
$$

where:

$$
\begin{aligned}
& \mathrm{X} \text { and } \mathrm{Y}=\text { the reciprocals of the substrate concentration and } \\
& \text { velocities respectively. } \\
& \mathrm{N}=\text { number of substrate concentrations employed. } \\
& \mathrm{Y}=1 / \text { observed velocity (or } 1 / \mu \text { Moles of } \mathrm{p} \text {-chloroaniline/ } \\
& \mathrm{min} / \mathrm{mg} \text { protein). } \\
& \mathrm{A}_{\mathrm{i}}=\mathrm{Km} / \mathrm{V} \text { max (where } \mathrm{Km} \text { is the Michaelis constant and }
\end{aligned}
$$

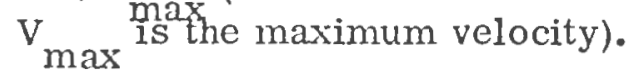

$$
\begin{aligned}
& \mathrm{X}=1 / \text { substrate concentration (or } 1 / \text { mNolar } \mathrm{p} \text {-chloro-N- } \\
& \text { methylaniline concentration. } \\
& A_{0} \quad=1 / \text { maximum velocity (or } 1 / V_{\max } \text { ). }
\end{aligned}
$$


The inhibition constant $\left(\mathrm{K}_{\mathrm{i}}\right)$ was calculated on the basis that the slope of a double reciprocal ( $1 / \mathrm{v}$ vs. $1 / \mathrm{s})$ plot is altered by the factor $\left(1+\mathrm{i} / \mathrm{K}_{\mathrm{i}}\right)$ in the presence of a competitive inhibitor (Mahler and Cordes, 1966).

where $\mathrm{i}=$ inhibitor concentration

and $\mathrm{K}_{\mathbf{i}}=$ inhibitor constant 
was given to controls. The animals were killed on day 5 and liver microsomal fractions prepared from these animals were assayed for aminopyrine demethylase and RNase activity.

The effects of two doses of $\mathrm{Pb}(50 \mathrm{mg} / \mathrm{kg}$ and $25 \mathrm{mg} / \mathrm{kg}$ twice daily for 4 days) on microsomal aminopyrine demethylase and RNase of intact adrenalectomized and hypophysectomized rats were qualitatively similar (Table 2). In all groups except one, Pb significantly increased aminopyrine demethylation and reduced microsomal RNase activity. In each experiment, $\mathrm{Pb}$ treatment of hypophysectomized and adrenalectomized rats resulted in less stimulation of aminopyrine demethylation or inhibition of RNase than that observed in intact rats. An inverse correlation between the Pb stimulation of aminopyrine demethylation and inhibition of microsomal RNase was observed in all experiments.

In order to determine whether the observed differences in ribonuclease were due to differences in the degree of lysosomal contamination, liver microsomal fractions from $\mathrm{Pb}$-treated (50 mg/kg 5 days) and control animals were assayed for $\beta$-glucuronidase activity which is localized in the lysosomal fraction of rat liver (DeDave, 1955). Phenolpthalein- $\beta$-glucuronidase activity of microsomal fractions obtained from $\mathrm{Pb}$-treated animals was not significantly $(P>0.05)$ different from controls thereby indicating that differential lysosomal contamination was not a factor in the reduction of RNase activity of Pb-treatedrat microsomes (Table 3).

Since differences (described earlier in this thesis) exist between the characteristics of $\mathrm{MC}$ and $\mathrm{Pb}$ induction of $\mathrm{DME}$, the following experiment was designed to determine the effect of MC induction on RNase activity of microsomal fractions. $\mathrm{MC}(40 \mathrm{mg} / \mathrm{kg})$ was administered to male rats for two days. Controls received the vehicle (corn oil). The animals were killed on the third day and microsomal fractions prepared from these animals were assayed for $\mathrm{p}$-nitroanisole demethylase and RNase activity. 
Table 2

Inhibition of Ribonuclease During Phenobarbital Induction of Microsomal Hepatic Drug-Metabolism in Intact. Adrenalectomized and Hypophysectomized Male Rats ${ }^{\mathrm{a}}$

\begin{tabular}{|c|c|c|c|}
\hline & Aminopyrine & Ribonuclease ${ }^{c}$ & $\begin{array}{l}\text { Liver Microsomal } \\
\text { Protein } \mathrm{mg} / \mathrm{gm}\end{array}$ \\
\hline Treatment $(\mathrm{N})$ & Mean \pm S.E. & Mean \pm S.E. & liver I S.E. $(\mathrm{N})$ \\
\hline
\end{tabular}
INTACT RATS

Control (6)

$59.8 \pm 2.9$

$0.230 \pm 0.027$

$21.0 \pm 0.82$

Phenobarbital

$25 \mathrm{mg} / \mathrm{kg}$ (5)

$91.2 \pm 4.7^{d}$

$0.105 \pm 0.021^{d}$

$27.1 \pm 2.9$

Phenobarbital

$50 \mathrm{mg} / \mathrm{kg}(6)$

$100.5 \pm 2.9^{d}$

$0.068 \pm 0.008^{d}$

$28.1 \pm 1.4^{d}$

\section{ADRENALECTOMIZED}

Control (6)

$50.2 \pm 1.9$

$0.161 \pm 0.019$

$19.9 \pm 0.9$

Phenobarbital

$25 \mathrm{mg} / \mathrm{kg}$ (5)

$65.4 \pm 2.5^{d}$

$0.114 \pm 0.020^{\mathrm{NS}}$

$24.0 \pm 1.7^{d}$

Phenobarbital

$50 \mathrm{mg} / \mathrm{kg}$ (11)

$69.9 \pm 3.0^{\mathrm{d}}$

$0.102 \pm 0.010^{d}$

$26.0 \pm 1.1$

\section{HYPOPHYSECTOMIZED}

Control (6)

$48.0 \pm 1.3$

$0.364 \pm 0.050$

$15.7 \pm 1.3$

Phenobarbital

$25 \mathrm{mg} / \mathrm{kg}$ (5)

$68.6 \pm 2.5^{\mathrm{d}}$

$0.150 \pm 0.014^{d}$

$24.1 \pm 1.9^{d}$

Phenobarbital

$50 \mathrm{mg} / \mathrm{kg}(8)$

$68.7 \pm 5.0^{d}$

$0.147 \pm 0.050^{d}$

$26.2 \pm 1.4^{d}$

a Forty-five day old intact (170-200 gm) adrenalectomized (150-200 gm) and hypophysectomized (100-120 gm) ymale rats received phenobarbital twice daily for 4 days and were sacrificed on day 5. Adrenalectomized and Hypophysectomized rats were used 2 weeks after operations.

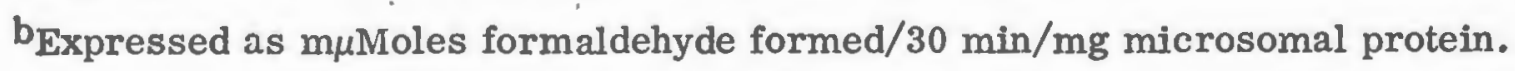

Cxpressed as optical density units at $260 \mathrm{m \mu} / 20 \mathrm{~min} / \mathrm{mg}$ microsomal protein.

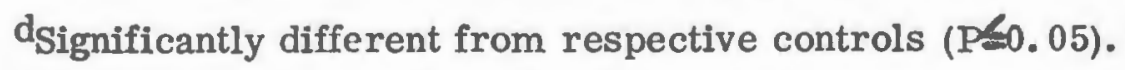

$\mathrm{NS}_{\text {Not }}$ significantly different from control $(p>0.05)$ 
Table 3

Phenolpthalein- $\beta$-Glucuronidase Activity of Microsomal Fractions Obtained from Livers of Normal and PhenobarbitalTreated Rats ${ }^{a}$

$\beta$-Glucuronidase $\mathrm{b}^{\mathrm{b}}$

Mean \pm S. E. (N)

Control

$43.2 \pm 1.2$

Phenobarbital

$46.0 \pm 4.7^{\mathrm{c}}$

${ }^{\text {a }}$ Values represent means + standard error of determinations from controls and rats $(375-410 \mathrm{gm})$ treated with phenobarbital $(50 \mathrm{mg} / \mathrm{kg})$ for 5 days.

b

${ }^{\mathrm{E}}$ Expressed as $\mathrm{m} \mu \mathrm{M}$ oles phenolpthalein formed $/ \mathrm{mg}$ protein $/ 15 \mathrm{~min}$.

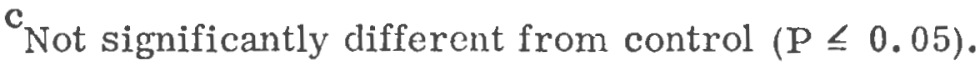


Two-day $\mathrm{MC}$ treatment $(40 \mathrm{mg} / \mathrm{kg})$ resulted in a significant $(\mathrm{P} \leq 0.05)$ three-fold stimulation of microsomal p-nitroanisole demethylation one day after termination of treatment (Table 4). However, this three-fold stinulation of microsomal p-nitroanisole demethylation is associated with a non-significant $(P>0.05)$ inhibition of RNase activity with this inducing agent. In Vitro Recombination Studies.

Microsomes and 105, $000 \mathrm{x} \mathrm{g}$ supernatant fractions obtained from control and $\mathrm{Pb}$-treated rats were recombined to determine the presence of any endogenous inhibitors of RNase (Table 5 and Table 6). Negligible RNase activity was found in supernatants from either control of $\mathrm{Pb}$-treated animals. Incubation of control supernatants with microsomes from $\mathrm{Pb}$-treated rats resulted in a 17 percent stimulation of RNase activity. Conversely, when microsomes from untreated animals were incubated with supernatants from $\mathrm{Pb}$-treated animals, control microsomal RNase activity was inhibited by 30 percent and 87 percent of control values in the two experiments (Table 5, Table 6).

Repetition of these experiments in the presence of p-chloromercuribenzoate $\left(10^{-6} \mathrm{M}\right)$ which is reported to inactivate the rat liver RNase inhibitor characterized by Shortman (1962) resulted in 33-132 percent stimulation of RNase in the incubation mixture composed of microsomes and supernates prepared from $\mathrm{Pb}$-treated animals (Table 6). In the incubation mixture composed of PCMB, control supernatant and control microsomal preparations 26 percent inhibition of RNase activity as observed. Addition of $\mathrm{p}$ chloromercuribenzoate to control microsomes incubated in the presence of $\mathrm{Pb}$ supernatant increased RNase by 13 percent but not to control levels. Boiled 105, $000 \mathrm{x} \mathrm{g}$ supernatant from $\mathrm{Pb}$-treated rats were still able to inhibit RNase activity of control microsomes.

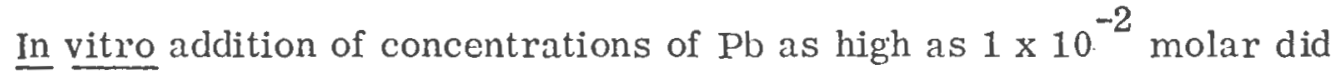
not influence RNase activity of microsomal fractions. Caffeine, barbital 
Table 4

Comparison of Effect of Induction by 3-Methylcholanthrene on Hepatic Microsomal P-Nitroanisole Demethylase Activity and Ribonuclease

\begin{tabular}{lll}
\hline Treatment $(\mathrm{N})$ & $\begin{array}{l}\text { P-Nitroanisole } \\
\text { Demethylase } \\
\text { Mean } \pm \mathrm{S} . \mathrm{E} .\end{array}$ & $\begin{array}{l}\text { Ribonuclease }^{\mathrm{b}} \\
\text { Mean } \pm \text { S.E. }\end{array}$ \\
\hline Control (5) & $3.46 \pm 1.52$ & $0.302 \pm 0.038$ \\
$\begin{array}{l}\text { 3-Methylcholanthrene } \\
(40 \mathrm{mg} / \mathrm{kg}, 2 \text { days) (5) }\end{array}$ & $13.77^{-3.52^{\mathrm{c}}}$ & $0.233 \pm 0.064^{\mathrm{d}}$ \\
\hline
\end{tabular}

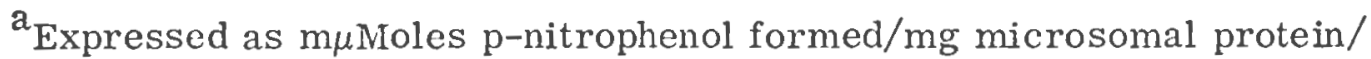
30 min. (male rats 190-280 gms).

bExpressed as optical density units at $260 \mathrm{~m} \mu / \mathrm{mg}$ microsomal protein $/ 20 \mathrm{~min}$.

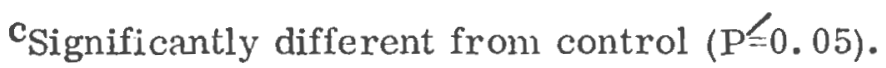

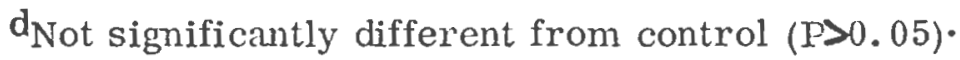


Table 5

In Vitro Inhibition of Microsomal Ribonuclease by $105,000 \times \mathrm{g}$ Liver Supernatant Fraction of the Phenobarbital-Treated Rat. ${ }^{a}$

\begin{tabular}{llc}
\hline Microsomes & Supernatant & RNase $^{\mathrm{b}}$ \\
\hline Control & & 0.331 \\
Phenobarbital & Control & 0.188 \\
Control & Phenobarbital & 0.370 \\
Phenobarbital & Phenobarbital & 0.160 \\
Control & Control & 0.258 \\
Phenobarbital & & 0.187 \\
\hline
\end{tabular}

${ }^{\mathrm{a}}$ One group of male (375-410 gm) rats was treated with $50 \mathrm{mg} / \mathrm{kg}$ phenobarbital for 5 days. All animals were killed 24 hours after the last treatment. Microsomes and supernatants used were obtained from one control and one $\mathrm{Pb}$-treated rat.

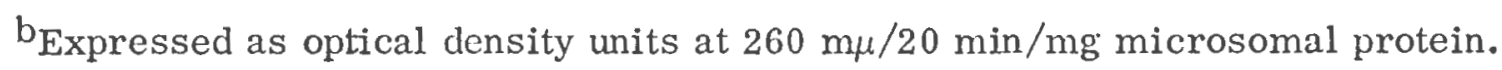




\section{Table 6}

Ribonuclease Inhibition in the Presence of P-Chloromercuribenzoate by $105,000 \times \mathrm{g}$ Supernatant Fraction Prepared from Livers of Phenobarbital-Treated ${ }^{\mathrm{a}}$ Rats.

\begin{tabular}{llll}
\hline Microsomes & Supernatant & PCMB $^{\mathrm{b}}$ & Ribonuclease $^{\mathrm{e}}$ \\
\hline Control & - & - & 0.151 \\
Phenobarbital & - & - & 0.057 \\
Control & -- & + & 0.120 \\
Phenobarbital & -- & + & 0.016 \\
Control & Control & -- & 0.231 \\
Control & Control & + & 0.144 \\
Phenobarbital & Phenobarbital & -- & 0.123 \\
Phenobarbital & Phenobarbital & + & 0.164 \\
Control & Phenobarbital & - & 0.031 \\
Control & Phenobarbital & + & 0.072 \\
Phenobarbital & Control & - & 0.159 \\
Phenobarbital & Control & + & 0.139 \\
& & & \\
\hline
\end{tabular}

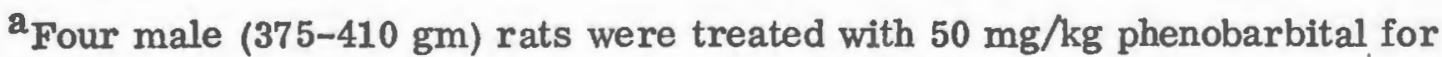
5 days. Controls were given distilled water. All animals were killed 24 hours after the last treatment.

$\mathrm{b}_{\text {Microsomes and supernatants used were pooled from liver fractions pre- }}$ pared from at least four animals.

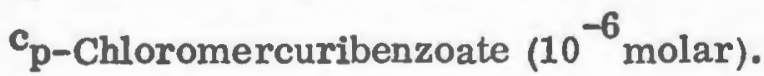

Mean of duplicate determinations (Optical Density $260 \mathrm{~m} \mu, / 20 \mathrm{~min} / \mathrm{mg} \mathrm{micro-}$ somal protein). 
$1 \times 10^{-4}$ molar and dibutryl cyclic amp $1 \times 10^{-6}$ molar did not alter RNase activity when added to the incubation medium.

In order to isolate the inhibitor material, $105,000 \mathrm{xg}$ supernatant fractions prepared from $\mathrm{Pb}$-treated and control rat livers were fractionated by 'Sephadex' column chromatography. Prior to column fractionation both preparations contained negligible activity. In both preparations, fractions eluted at void volumes of the' Sephadex' column were found to contain RNase activity, while fractions eluted after void volume possessed RNase inhibitor activity. However, no differences in the elution profiles or in RNase activity stimulation or inhibition was observed between the two preparations. These results suggested that the RNase inhibitor in preparations from $\mathrm{Pb}$-treated rats was inactivated or bound to the 'Sephadex' gel. Amphetamine Inhibition of P-Chloro-N-Methylaniline (PCMA) Demethylation.

In order to determine the effect of d-amphetamine on PCMA demethylation, parallel incubations were carried out in the presence and absence of $3 \times 10^{-3}$ molar d-amphetamine sulfate. Data plotted in Figure 1 indicate that d-amphetamine sulfate inhibits PCMA demethylation competitively in liver preparations from male and female rats. Kinetic constants presented in Table 1 indicate that the apparent $\mathrm{K}_{\mathrm{m}}$ for PCMA demethylase activity of female rat liver is approximately 2 times that for male liver. Conversely, the maximum velocity of the female preparation is approximately two-thirds the corresponding value for the male rat liver enzyme. D-amphetamine sulfate increased the apparent $\mathrm{K}_{\mathrm{m}}$ of both preparations two-fold, while $\mathrm{V}_{\max }$ is virtually unchanged. Inhibition constants for the two preparations are similar i.e., 2.5 and $2.7 \times 10^{-3}$ Molar for the male and female rat liver preparations respectively.

Amphetamine inhibited PCMA demethylation when $8 \times 10^{-3}$ molar NADPH was substituted for the NADPH-generating system. No differences in apparent p-chloroaniline formation by boiled supernatants were observed in the presence or absence of amphetamine in the incubation mixture. These results suggested 
that amphetamine inhibition was not due to either interference with the NADPH-generating system or development of color. 
Fig. 2. Lineweaver-Burk plot of p-chloro-N-methylaniline demethylation by male and female rat liver $9000 \mathrm{x}$ g supernatant in the presence and absence of 3 mMolar d-amphetamine sulfate. PCMA = p-chloro-N-methylaniline; $\mathbf{P C A}=\mathrm{p}$-chloroaniline.

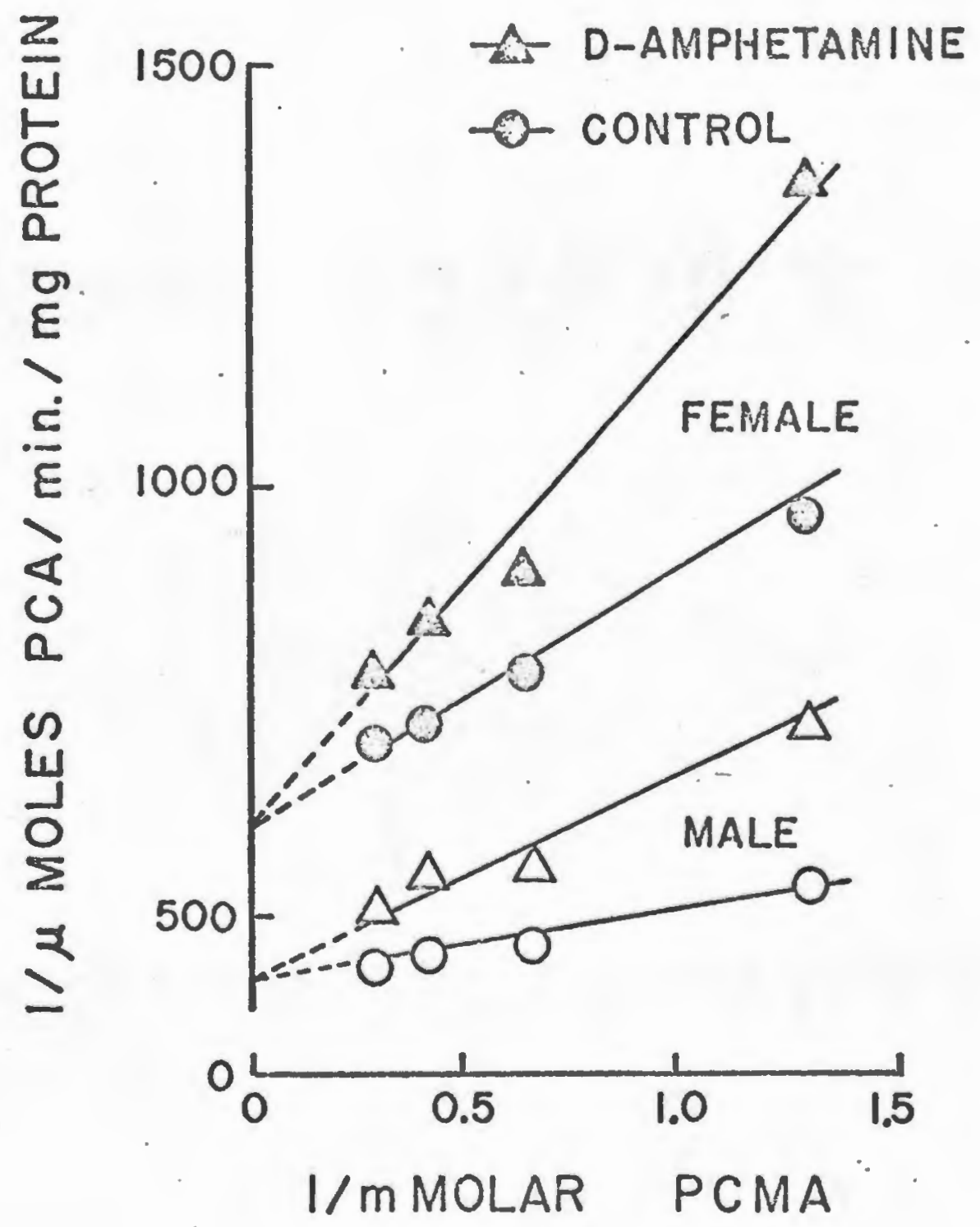




\section{Table 7}

Kinetic constants for D-Amphetamine Sulfate Inhibition of P-Chloro-N-Methylaniline Demethylation by Rat Liver 9000 x g Supernatant Fractions.

Apparent

Kinetic Constants

Control

Amphetamine

Adult Male Preparation

$\mathrm{K}_{\mathrm{m}}^{\mathrm{a}}$

0.25

0.54

$v_{\text {max }}$

2.5

2.4

$\mathrm{K}_{1}^{\mathrm{c}}$

$--$

2.5

Adult Female Preparation

$\mathrm{K}_{\mathrm{m}}{ }^{\mathrm{a}}$

0.49

1. 0

$v_{\max }$

1.7

1.8

$\mathrm{K}_{1} \mathrm{c}$

$--$

2.7

${ }^{2}$ Expressed as mMolar p-chloro-N-methylaniline concentration.

bExpressed as m $\mu$ Moles p-chloroaniline formed $/ \mathrm{min} / \mathrm{mg}$ protein.

Expressed as mMolar d-amphetamine sulfate concentration.

$\mathrm{d}_{\text {Kinetic constants were calculated from slope and intercepts determined }}$ according to the method of least squares. 


\section{DISCUSSION}

Inhibition of Microsomal Ribonuclease During Phenobarbital Induction.

Previous investigations have reported that $\mathrm{Pb}$ induction of $\mathrm{DME}$ is associated with increased liver protein and enhancement of RNA synthesis. These findings are consistent with the observed suppression of RNase activity by microsomal preparations from $\mathrm{Pb}$-treated rats. Conversely, three-fold stimulation of DIIE by MC treatment does not significantly reduce microsomal RNase. The findings reported here are consistent with earlier published data which suggest that $\mathrm{Pb}$ and $\mathrm{MC}$ induce $\mathrm{DME}$ through different mechanisms.

The suppression of microsomal RNase reported here, when combined with previously documented enhanced activity of nuclear RNA polymerase, provide a mechanism to explain the increased amount of microsomal RNA, protein (Orrenius et al., 1965) decreased breakdown of microsomal RNA (Mycek and Nemeth, 1967; Mycek, In Press), prolongation of ribosomal RNA half-life following $\mathrm{Pb}$ treatment (Steele, 1970) as well as the increased capacity for protein synthesis which occur in livers of $\mathrm{Pb}$-treated rats (Kato et al. , 1966).

Inhibition of RNase activity in hypophysectomized, and adrenalectomized rats during induction of $\mathrm{DME}$ by $\mathrm{Pb}$ indicates that intact adrenals or pituitary glands are not required for RNase inhibition by $\mathrm{Pb}$. However, these data do not exclude the involvement of these glands in the $\mathrm{Pb}$ inhibition of RNase of intact animals. Ribonuclease inhibition was not as extensive in hypophysectomized or adrenalcctomized rats. with the least inhibition of RNase following $\mathrm{Pb}$ treatment observed in adrenalectomized rats. These findings are consistent with the suggestion of Orrenius et al., (1969) that steroid hormones may be involved in the maintenance of inducibility of rat liver DME.

RNase inhibition appears to result from increased levels of a RNase inhibitor in cell sap obtained from livers of $\mathrm{Pb}$-treated rats. Inhibition is not duc to a direct effect of $\mathrm{Pb}$ on RNase since addition of $\mathrm{Pb}$ does not result in RNase inhibition in vitro (Louis-Ferdinand and Fuller, 1970). These 
results are in agreement with those of Mycek (Biochem. Pharmacol. In Press) who was not able to observe inhibition of microsomal nucleic acid degradation following direct adclition of $\mathrm{Pb}$ to the incubation mixture.

RNase inhibition does not appear to be attributable to the inhibitor described by Shortman (1962). He reported that the rat liver RNase inhibitor was completely inactivated in the presence of $10^{-6}$ molar p-chloromercuribenzoate. As a result of the inactivation of RNase inhibitor, latent RNase was activated. Mycek (Biochem. Pharmacol. In Press) reported that PCMB concentrations in excess of $10^{-3}$ molar stimulated breakdown of endogenous microsomal nucleic acid in preparations from control and $\mathrm{Pb}$-treated rats. However, microsomal RNA breakdown in preparations from $\mathrm{Pb}$-treated rats following in vitro addition of PCMB was still less than control values.

Inhibition of RNase may play a dominant role in the induction by $\mathrm{Pb}$ of DME in hypophysectomized animals, since no stimulation of RNA polymerase activity is observed in nuclei of Pb-treated rats (Nebert and Gelboin, 1969; Wilson et al. , 1967). Inhibition of RNA degradation may account for the enhancement of microsomal amino acid incorporating activity (Jondorf et al., 1966) and stimulation of drug metabolism observed in hypophyscctomized rats (Conney, 1961) following administration of $\mathrm{Pb}$.

Inhibition of RNase might be attributed to dilution of RNase activity resulting from increases in non-RNase liver microsomal protein. However, this is not likely since microsomal protein content is increased only 1.5 fold after induction with 5 doses of $\mathrm{Pb}(100 \mathrm{mg} / \mathrm{kg}$ ) (Orrenius et al. , 1965). Greater increases (viz. 5-times) in microsomal protein would conceivably be required for dilution to account for the RNase inhibition which was observed 24 hours following a single dose of $\mathrm{Pb}$. It is difficult to demonstrate significant increases in microsomal protein 24 hours after a single dose of $\mathrm{Pb}$. Since microsomal protein is increased only 1.5 fold, dilution would account for only a 33 percent inhibition of RNase rendering it unlikely that the RNase inhibition observed in these studies can be attributed to dilution of RNase specific activity by microsomal protein. 
Competitive Inhibition by D-Amphetamine of Oxidative Demethylation.

D-Amphetamine sulfate competitively inhibited PCMA demethylation by hepatic $9000 \mathrm{xg}$ supernatant fractions prepared from male and female rats. This finding confirms and extends earlier observations (Lal et al., 1970) concerning amphetamine inhibition of hexobarbital oxidase activity. Major sex differences in sensitivity to amphetamine inhibition of DNE were not apparent since the amphetamine inhibition constants for the two preparations were similar. This inhibition did not appear to be attributable to interference by amphetamine with NADPH-generation since inhibition was obtained when NADPH was added directly in place of the generating system. Comparison of control male and female rat liver PCMA demethylase kinetic constants (Table 7) indicated that PCMA demethylation proceeded at a higher maximum velocity in preparations from male rats. Apparent sex differences in substrate dependence of PCMA demethylase are reflected by the respective $\mathrm{K}_{\mathrm{m}}$ values (male (0.25) female (0.49 mMolar) PCMA). Shenkman et al., (1967) have reported similar sex differences in hexobarbital oxidase activity. The data indicate that sex differences in apparent PCMA demethylase maximal velocities are approximately half those observed with hexobarbital oxidase.

As mentioned earlier, it has been reported that alternate substrates of microsomal drug metabolizing enzymes can competitively inhibit the metabolism of one another. Since d-amphetamine is hydroxylated in vivo the competitive inhibition of PCMA demethylation reported here may be attributed to competition by amphetamine as an alternate substrate. This does not appear to be the situation since it has been reported that neither microsomal preparations (Groppetti and Costa, 1969) nor 10,000 x g rat liver supernatants (Dingle and Bass, 1969) metabolize d-amphetamine to any appreciable extent. However, the data do not exclude the possibility that amphetamine may otherwise interact with microsomal drug metabolism.

Amphetamine inhibition of hexobarbital oxidase is observed at inhibitor concentrations similar to those used in this investigation. The apparent 
amphetamine inhibition constant calculated from the data of Lal et al., (1970) viz. $4 \times 10^{-3}$ Molar is similar to the amphetamine inhibition constant determined in PCMA demethylase studies (viz. 2.5-2.7 x 10 $0^{-3}$ Molar). Other amphetamine derivatives inhibit hepatic oxidative demethylation. P-Chloroamphatamine ( $\mathrm{K}_{\mathrm{i}} ; 0.4 \times 10^{-3}$ Molar) p-hydroxyamphetamine ( $\mathrm{K}_{\mathrm{i}} ; 24 \times 10^{-3}$ Molar) and methamphetamine ( $\mathrm{K}_{\mathrm{i}} ; 61 \times 10^{-3}$ Molar) inhibit PCMA demethylation by male rat liver $9000 \mathrm{xg}$ supernatant fractions (Louis-Ferdinand et al., 1970). Methylphenidate, a related phenethylamine derivative, inhibits imipramine metabolism in mouse and rat liver. Inhibition by methylphenidate has been reported at concentrations similar to those at which amphetamine and amphetamine derivatives inhibit PCMA demethylase. Similar inhibition constants for imipramine metabolism, hexobarbital oxidase, or PCMA demethylase may be attributable to an interaction by phenethylamine derivatives with a common component of these enzyme systems. 


\section{CONCLUSIONS AND SUMMARY}

1) Phenobarbital induction of rat liver microsomal drug metabolism is associated with a dose-related inhibition of ribonuclease activity of microsomal fractions isolated from these animals, which is not attributable to differential lysosomal contamination between preparations from control and $\mathrm{Pb}$-treated animals.

2) Phenobarbital inhibition of RNase does not require the presence of an intact pituitary-adrenal axis nor is the presence of either gland required for the inhibition of RNase by $\mathrm{Pb}$. The data do not exclude the-possibility that the presence of these glands enhances the response of intact rats to inducing doses of phenobarbital.

3) Maximal suppression of Liver Microsomal Ribonuclease Activity is an early occurrence during induction of drug-metabolizing enzymes. Significant reduction of ribonuclease occurs prior to a significant increase in $\mathrm{p}$-chloro- $\mathrm{N}$-methylaniline demethylase activity. An inverse relationship exists between PCMA demethylase activity and ribonuclease during $\mathrm{Pb}$ induction.

4) Induction of p-nitroanisole demethylation during treatment with 3methylcholanthrene does not result in a significant $(P>0.05)$ inhibition of microsomal ribonuclease activity.

5) Inhibition of ribonuclease is associated with the presence of a heat-stable inhibitor in the cell sap obtained from livers of phenobarbital-treated rats.

6) Inhibition of ribonuclease during phenobarbital induction is not attributable to a direct effect of phenobarbital on ribonuclease since addition of phenobarbital to the incubation medium does not influence RNase activity.

7) D-Amphetamine sulfate competitively inhibits p-chloro-N-methylaniline demethylation by $9000 \mathrm{x}$ g supernatant fractions prepared from both male and female rat livers. 
8) These findings are consistent with and support the hypothesis that inhibition of RNA degradation occurs during induction of drug metabolizing enzymes by phenobarbital. It is proposed that this constitutes a major mechanism by which this drug increases liver RNA, and enhances protein synthesis and thereby stimulates the synthesis of drug metabolizing enzymes. The data provide evidence for the concept that the altered degradation of RNA is a drug-vulnerable metabolic control mechanism. 


\section{RESULTS}

Inhibition of Ribonuclease During Induction by Phenobarbital.

Male rats (weighing 400-550 gms) were treated daily with $\mathrm{Pb}$ for 6 days and sacrificed 24 hours or 72 hours after the last $\mathrm{Pb}$ administration. When rats were sacrificed 24 hours after the last $\mathrm{Pb}$ treatment (100 $\mathrm{mg} / \mathrm{kg}$ ) aminopyrine demethylase activity was increased five-fold and the RNase activity associated with rat liver microsomes was reduced to 1 to $2 \%$ of control values (Table 1.). When rats were sacrificed 72 hours after termination of $\mathrm{Pb}$ treatment, the magnitude of the total change was not as great as observed at 24 hours. Although neither of these values were significantly different from the 24 hours values, the RNase appeared to increase while aminopyrine demethylase decreased toward control values. When this experiment was repeated with microsomes of rats sacrificed 1 day following 5 daily treatments of $\mathrm{Pb}$ at a reduccd daily dose of $50 \mathrm{mg} / \mathrm{kg}$ stimulation of aminopyrine demethylase was again associated with a significant $\left(\mathrm{P}_{-} 0.05\right)$ reduction of RNase.

In order to further characterize the suppression of RNase during Phenobarbital induction, one dose $(100 \mathrm{mg} / \mathrm{kg})$ of Phenobarbital was given to 20 male (250-300 gm) rats. Animals were killed at 24 hours intervals for 5 days. Administration of one dose of $\mathrm{Pb}(100 \mathrm{mg} / \mathrm{kg})$ to male rats resulted in a significant $(P \leq 0.05)$ enhancement of microsomal oxidative demethylation of PCMA after 48 hours which persisted for 4 days (Fig. 1). Twenty-four hours after $\mathrm{Pb}$ treatment, RNase activity of microsomal fractions was reduced to the lowest point observed, approximately $20 \%$ of control values. Microsomal RNase was significantly depressed from control for 4 days.

As mentioned earlier RNase activity has been reported to change in response to treatment with cortisone or growth hormone. Therefore, the following experiment was designed to determine whether intact pituitary or adrenal glands were required for the obscrved effects of $\mathrm{Pb}$ on RNase activity. Phenobarbital (50 mg/ $\mathrm{kg}$ or $25 \mathrm{mg} / \mathrm{kg}$ twice daily for 4 days)was administered to intact, adrenalectomized or hypophysectomized male rats. Distilled water 
Table 1

Inhibition of Hepatic Ribonuclease During Induction of Microsomal Aminopyrine Demethylase by Phenobarbital

Table $1 \mathrm{a}$

Influence of Phenobarbital $(100 \mathrm{mg} / \mathrm{kg})$ Administration ${ }^{2}$

\begin{tabular}{|c|c|c|c|c|}
\hline Group $(\mathrm{N})$ & $\begin{array}{l}\text { Ribonuclease }{ }^{b} \\
\text { Mean }{ }_{-}^{+} \text {S. E. }\end{array}$ & $\begin{array}{l}\text { Percent } \\
\text { of } \\
\text { Control }\end{array}$ & $\begin{array}{l}\text { Aminopy rine } \\
\text { Demethylase } \\
\text { Mean } \pm \text { S. E. }\end{array}$ & $\begin{array}{l}\text { Percent } \\
\text { of } \\
\text { Control }\end{array}$ \\
\hline Control (4) & $0.131 \pm 0.056$ & 100 & $17.7^{+}-1.7$ & 100 \\
\hline $\begin{array}{l}\text { Killed on } \\
\text { Day } 7(3)\end{array}$ & $0.004 \pm 0.002^{\mathrm{d}}$ & 1.3 & $93.4 \pm 10.9^{d}$ & 527. \\
\hline $\begin{array}{l}\text { Killed on } \\
\text { Day } 9 \text { (3) }\end{array}$ & $0.018 \pm 0.015^{\mathrm{d}}$ & 5.8 & $72.2^{+}-7.6^{\mathrm{d}}$ & 408. \\
\hline
\end{tabular}

Table $1 b$

Influence of Phenobarbital (50 mg/kg) Administration ${ }^{\mathrm{e}}$

\begin{tabular}{llclc}
\hline Group (N) & $\begin{array}{l}\text { Ribonuclease } \\
\text { Mean } \pm \text { S. E. }\end{array}$ & $\begin{array}{c}\text { Percent } \\
\text { of } \\
\text { Control }\end{array}$ & $\begin{array}{l}\text { Aminopyrine } \\
\text { Demethylase } \\
\text { Mean } \pm \text { S. E. }\end{array}$ & $\begin{array}{c}\text { Percent } \\
\text { of } \\
\text { Control }\end{array}$ \\
\hline $\begin{array}{l}\text { Control (5) } \\
\begin{array}{l}\text { Phenobarbital } \\
\text { Treated (4) }\end{array}\end{array}$ & $0.357^{+} 0.039$ & 100 & $8.7^{+} 3.2$ & 100 \\
\hline
\end{tabular}

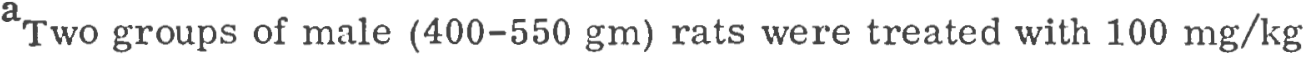
phenobarbital for 6 days. Controls received distilled water.

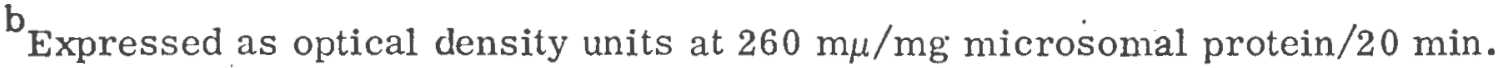

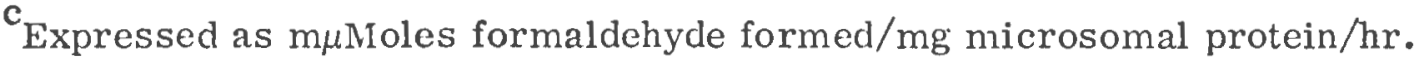

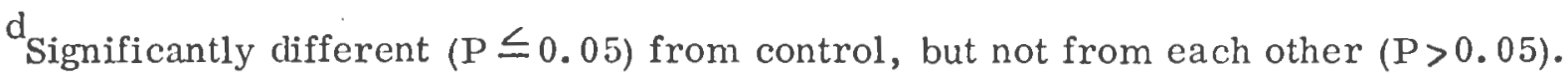

One group of male (375-410 gm)rats was treated with $50 \mathrm{mg} / \mathrm{kg}$ phenobarbital for 5 days. Controls received distilled water. All animals were killed 24 hours after the last treatment.

$\mathrm{f}_{\text {Significantly different }(\mathrm{P} \leq 0.05) \text { from control. }}$ 
Fig. 1 Effect $^{\mathrm{a}}$ of Phenobarbital ${ }^{\mathrm{b}}$ on Rat Hepatic Ribonuclease During Stimulation of Microsomal Oxidative Demethylation.
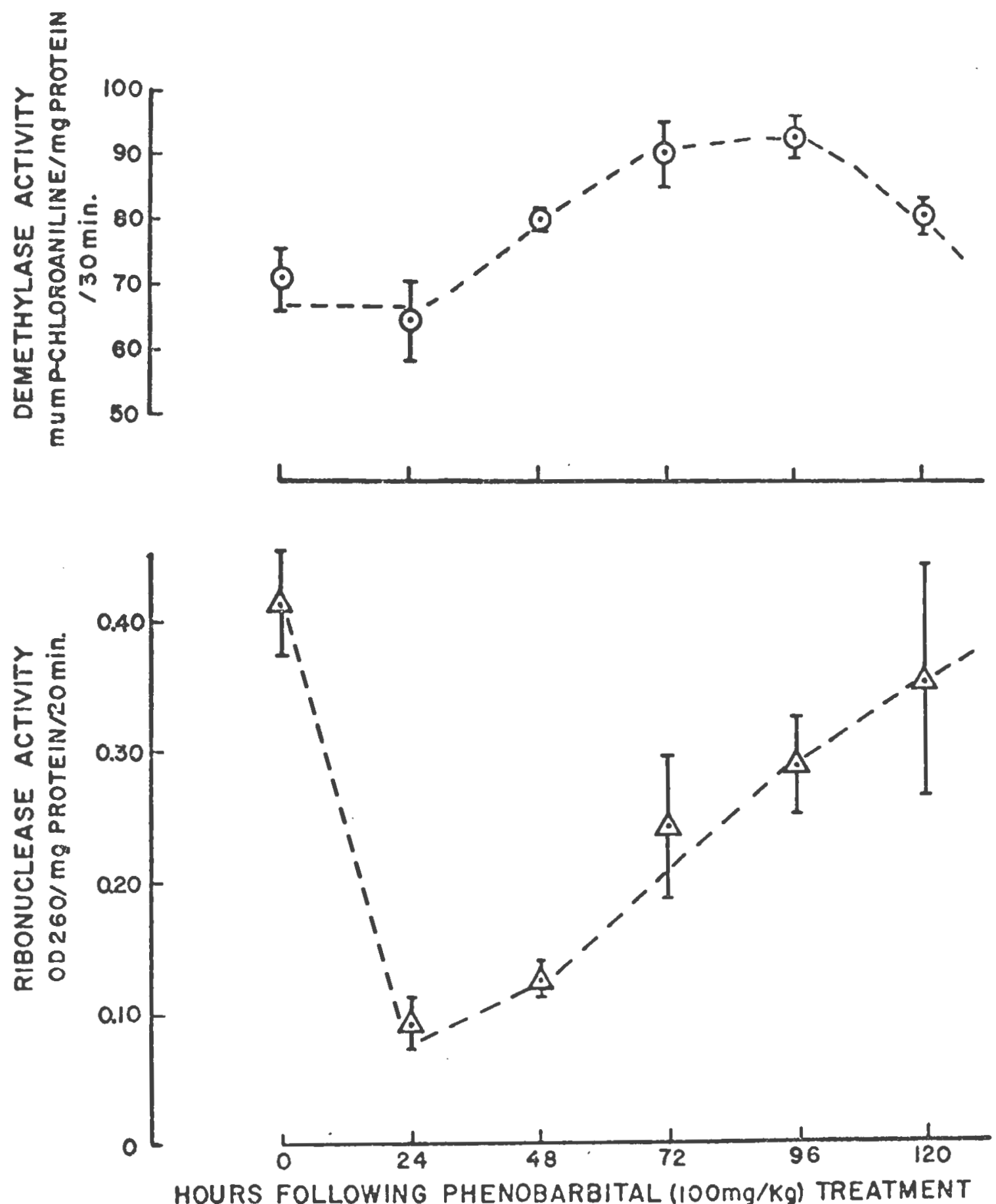

HOURS FOLLOWING PHENOBARBITAL $(100 \mathrm{mg} / \mathrm{Kg})$ TREATMENT 


\section{References}

Arias, I. M., Doyle, D. and Schimke, R.T.: Studies on the synthesis and degradation of proteins of the endoplasmic reticulum of rat liver. J. Biol. Chem. 244: 3305-3315, 1969.

Axelrod, J.: Studies on sympathomimetic amines II The biotransformation and physiological disposition of $d$-amphetamine and d-methamphetamine. $J$. Pharmacol. Exp. Therap. 110: 315-326, 1954.

Barnabei, O. and Ottolengi, C.: Glucocorticoid control of nuclear synthesis and of microsomal hydrolysis of ribonucleic acid and its possible significance in the hormonal response of liver. Advance: Enzyme Regulation. 6: 189-209,1968.

Barnard, E.A.: Ribonucleases, A. Rev. Biochem. 38: 677-732, 1969.

Baron, J. and Tephly, T. R.: Effect of 3 amino 1,2, 4 triazole on the stimulation. of hepatic microsomal heme synthesis and induction of hepatic microsomal oxidases producted by phenobarbital. Molec. 'Pharmacol. 5: 10-20, 1969.

Barondes, S. H. and Nirenberg, M.W.: Fate of a synthetic polynucleotide directing cell-free protein synthesis I Characteristics of degradation. Science. 138: $810-813,1962$.

Bendana, F. E. and Galston, A. W.: Hormone induced stabilization of soluble RNA in pea stem. Science. 150: 69-70, 1965.

Bermhard, R.: Enzymes their ups and clowns in animal cells. Scientific Research 10 Nov. 1969 pp 30-33.

Blobel, G. and Potter, V. R.: Relation of ribonuclease and ribonuclease inhibitor to the isolation of polysomes from rat liver. Proc. Natn. Acad. Sci. U.S.A. 55: $1283-1888,1966$.

Brazda, F. G., Heidngsfelder, S. and Martin, M.: Effect of Niliethamide on pentobarbital sleeping time in various animal species.: Comp. Biochen. Physiol. 14: $239-244,1965$.

Bresnick, E. and Madix, J. C.: Activation of chromatin by 3-Methylcholanthrene. In Microsomes and Drug Oxidations ed. by J. R. Giliette, A. H. Conney, G. J. Cosmides, R. W. Estabrook, J. R. Fouts and G. J. Mannering, pp. 431-452, Academic Press, New York, 1969. 
Bresnick, E. and Mosse, H. : Activation of genetic transcription in rat liver chromatin by 3-methylcholanthrene. Mol. Pharmacol. 5: 219-226,1969.

Bresnick, E., Williams, S. and Mosse, H.: Rates of turnover of deoxythymidine kinase and of tis template RNA in regenerating and control liver. Cancer Res. 27: 469-475, 1967.

Brewer, E. N., Foster, L. B., and Sells, B. H.: A possible role for ribonuclease in the regulation of protein synthesis in normal and hypophysectomized rats. J. Biol. Chem. 244: 1389-1392, 1969.

Brown, R. R., Miller, J. A. and Miller, E. C.: The metabolism of methylated aminoazo dyes. IV. Dietary factors enhancing demethylation in vitro. J. Biol. Chem. 209: 211-222, 1954.

Busch, H. In Histones and Other Nuclear Proteins p35, pp 236-238, Academic Press, New York, 1965.

Castles,J. J. and Singer, M. F.: Degradation of polyuridylic acid by ribonuclease II Protection by ribosomes. J. Mol. Biol 40: 1-17, 1969.

Claude, A.: Microsomes, endoplasmic reticulum and interactions of cytoplasmic membranes In Microsomes and Drug Oxidations ed. by J.R. Gillette, A. H. Conney, G. J. Cosmides, R. W. Estabrook, J. R. Fouts, G. J. Mannering, pp 3-39, Academic Press, New York, 1969.

Conney, A. H.: Enzyme induction and drug toxicity In Proceedings of the Second International Pharmacological Meetings, Vol. 4 pp 277-297, Macmillan Company, New York, 1965.

Conney, A. H.: Pharmacological implications of microsomal enzyme induction. Pharmacol. Rev. 19: 317-366, 1967.

Conncy, A. H., Burns, J. J.: Factors influencing drug metabolism. Adv. Pharmacol. 1: 31-58, 1962.

Conney, A. H., Davison, C., Gastel, R. and Burns, J. J.: Adaptive increases in drug-metabolizing enzymes induced by phenobarbital and other drugs. J. Pharmacol. Exp. Therap. 130: 1-8, 1960.

Conney, A. H. and Gilman, A. G.: Puromycin inhibition of enzyme induction by 3-methylcholanthrene and phenobarbital. J. Biol. Chem, 238: 3682-3685, 1963. 
Conney, A. H., Michaelson, I. A. and Burns, J. J.: Stimulatory effect of chlorcyclizine on barbituate metabolism. J. Pharmacol. Exp. Therap. 132: 202-206, 1961.

Conncy, A. H., Miller, E. C., and Miller, J. A.: The metabolism of methylated aminoazo dyes. V. Evidence for induction of enzyme synthesis in the rat by 3-methylcholanthrene. Cancer Res. 16: 450-459, 1956.

DeDuve, C., Pressman, B. C., Gianetto, R., Wattiaux, R. and Appelmans, F.: Tissue fractionation studies VI. Intracellular distribution patterns of enzymes in rat-liver tissue. Biochem. J. 60: 604-617, 1955.

Dingel, J. V. and Bass, A.D.: Inhibition of the hepatic metabolism of amphetamine by desipramine. Biochem. Pharmacol. 18: 1535-1538, 1969.

Ernster, L. and Orrenius, S.: Substrate-induced synthesis of the hydroxylating enzyme system of liver microsomes. Fed. Proc. 24: 1190-1199, 1965.

Fuller, G. C., Olshan, A. M. and Lal, H.: The stimulatory effect of phenobarbital on the $\mathrm{N}$-demethylation of $\mathrm{p}$-chloro-N-methylaniline. Life Sci. 8 : 383-387, 1969.

Gelboin, H. V., Wortham, J. S. and Wilson, R. G.: 3-Methylcholanthrone and phenobarbital stimulation of rat liver RNA polymerase. Nature 214: $281-283,1967$.

Gelboin, H.V., Wortham, J.S. and Wilson, R. G.: Rapid and marked inhibition of rat-liver RNA polymerase by aflatoxin B1. Science 154: 12051206, 1966.

Gelboin, H. V. and Blackburn, N: The stimulatory effect of 3-methylcholanthrene on benzpyrene hydroxylase activity in several rat tissues: Inhibition by actinomycin-D and puromycin. Cancer Res.: 24: 356-360, 1964.

Gelboin, H. V.: Studies on the mechanims of methylcholanthrene induction of enzymc activities II. Stimulation of microsomal and ribosomal aminoacid incorporation. The effects of polyuridylic acid and actinomycin D. Biochim. Biophys. Acta 91: 130-144, 1964.

Greene, N. M.: The metabolism of drugs employed in anesthesia. Anesthesiology 29: $327-360,1968$.

Gribnau, A.A.M., Schocnmakers, J.G.G., VanKraaikamp, M. and Bloemendal, H.: High purification of the RNase inhibitor from rat liver by affinity chromatography. Biochem. Biophys. Res. Commun. 38:1064-1068,1970. 
Gropetti, A. and Costa, E.: Factors affecting the rate of disappearance of amphetamine in rats. Int. J. Neuropharmac. 8: 209-215, 1969.

Holtzman, J.L.: Effect of chronic phenobarbital administration on the turnover of hepatic microsomal protein. Biochem. Pharmacol. 18: 2573$2576,1969$.

Holtzman, J. L. and Gilette, J.R.: The effect of phenobarbital on the synthesis of microsomal phospholipid in female and male rats. Biochem. Biophys. Res. Commun. 24: 639 643, 1966.

Igarashi, S. J.: In vitro protein symthesis directed by $\mathrm{R}-17$ viral ribonucleic acid III. On the fate of mRNA in the cell-free system. Can. J. Biochem. 47: $1179-1186,1969$.

Inmie, R.C., and Hutchinson, W.C.: Changes in the activity of rat adrenal ribonuclease and ribonuclease inhibitor after administration of corticotrophin. Biochim. Biophys. Acta 108: 106-113, 1965.

Jick, H. and Shuster, L.: The turnover of microsomal reduced nicotinamide adenine dinucleotide phosphate cytochrome $c$ recluctase in the livers of mice treated with phenobarbital. J. Biol. Chem. 241: 5366-5369, 1966.

Jondorf, W. R., Simon, D. C. and Avnimelech, M.: The stimulation of aminoacid incorporation in a mammalian system with phonobarbital, 3-methylcholanthrene and cycloheximide. Biochem. Biophys. Res. Commun. 22: 644-649, 1966.

Kato, R., and Chiesara, E.: Increase of phenobarbitone metabolism induced in rats pretreated with some centrally acting compounds. Brit. J. Pharmacol. 18: 29-38, 1962 .

Kato, R., Chiesara, F. and Vassanelli, P.: Further studies on the inhibition and stimulation of microsomal drug-metabolizing enzymes of rat liver by various compounds. Biochem. Pharmacol. 13: 69-83, 1964.

Kato, R., Jondorf, W.R., I،oek, L.A., Ben, T. and Gelboin, H. V.: Studies on the mechanism of drug-induced microsomal enzyme activities V. Phenobarbital stimulation of endogenous messenger RNA and polyuridylic aciddirected $\mathrm{L}\left({ }^{14} \mathrm{C}\right)$-phenylalanine incorporation. Nol. Pharmacol. 2: 171-186,1966.

Kato, R., Loeb, L. and Gelboin, H. V.: Microsome-specific stimulation by phenobarbital of aminoacid incorporatici in vivo. Biochem. Pharmacol. 14: $1164-1166,1965$.

Kato, R., Takanaka, A., Onoda, K. and Omori, Y.: Lack of inhibitory action of aflatoxin on the induction of drug-metabolizing activities of liven nicrosomes by phenobarbital. Jap. J. Pharmacol. 19: $470-472,1969$. 
Kato, R. and Vassanelli, P.: Induction of increased meprobamate metabolism in rats pretreated with some neurotropic drugs. Biochem. Pharmacol. 11: $779-794,1962$.

Kenny, F. T.: Turnover of rat liver tyrosine transaminase: Stabilization after inhibition of protein synthesis. Science. 156: 525-528, 1967.

Kraft, N., Shortman, K. and Jamieson, D.: The effect of x-irradiation on the balance between the alkaline ribonuclease inhibitor of mammalian tissue. Radiat. Res. 39: 655-668., 1969.

Kupfer, D. and Bruggeman, L. L.: Determination of enzymic demethylation of p-chloro-N-methylaniline. Assay of aniline and p-chloroaniline. Anal. Biochem. 17: 502-512, 1966.

Lal, H., Puri, S. K. and Fuller, G. C.: Inhibition of hepatic hexobarbital metabolism by dextroamphetamine. Psychopharmacologia (Berl.) 16: 395$398,1970$.

Lamana, C. and Mallette, M. F.: Magnesium ion, an inhibitor of ribonuclease activity. Archs. Biochem. Biophys. 24: 451-458, 1949.

Lawford, G. R. and Schacter, H.: Stabilization of rat liver polyribosomes by endogenous ribonuclease inhibitor. Can. J. Biochem. 45: 144-148, 1967.

Lineweaver, H. and Burk, D.: The determination of enzyme dissociation constants. J. Am. Chem. Soc. 56: 658-666, 1934.

Locb, L. A. and Gelboin, H. V.: Mrethylcholanthrene-induced changes in rat liver nuclear RNA. Proc. Natn. Acad. Sci. U.S.A. 52: 1219-1226, 1964.

Louis-Ferdinand, R. T. and Fuller, G. C.: Suppression of Hepatic ribonuclease during phenobarbital stimulation of drug metabolism. Biochem. Biophys. Res. Comm. 38: 811-816, 1970 .

Louis-Ferdinand, R.T., Puri, S.K., Kowal, F., Fuller, G. and Lal, H.: Inhibition of hepatic drug metabolism by amphetamine, methamphetamine, hydroxyamphetamine and chloramphetamine. Abstracis: Society of 'Toxicology Ninth Annual iveeting at Atlanta Ga., 1970.

Lowry, O.H., Rosebrough, N.J., Farr, A. L. and Iandall, R. J.: Protein mcasurement with the folin phenol reagent. J. Biol. Chem. 193: 265-275, 1951. 
Mahler, H.R. and Cordes, E. H. : In Biological Chemistry. p 250, Harper and Row, New York, 1966.

Mannering, G.J., Sladek, N.E., Parli, C.J. and Shoeman, D. W.: Formation of a new P-450 hemoprotein after treatment of rats with polycyclic hydrocarbons. In Microsomes and Drug Oxidations, ed. by J. R. Gillette, A. H. Conney, G. J. Cosmides, R.W. Estabrook, J.R. Fouts, G.J.Mannering, pp. 303-330, Academ ic Press, New York, 1969.

Marver, H.S.: The role of heme in the synthesi and repression of microsomal protein, In Microsomes and Drug Oxidations, ed. by J. R. Gillette, A. H. Conney, G. J. Cosmides, R.W. Estabrook, J.R. Fouts, G. J. Mannering, pp 495-515, Academic Press, New York, 1969.

McMahon, R.E. and Easton, N.R.: The N-demethylation of butynamine. J. Pharmacol. Exp. Therap. 135: 128-133, 1962.

Meisler, A. I. and Tropp, B. E.: Studies on ribonucleic acid synthesis in nuclei isolated from rat liver. Biochem. Biophys. Acta 174: 476-490, 1969.

Muramatsu, M. and Busch, H.: Effects of thioacetamide on metabolism of proteins of normal and regenerating liver. Cancer Res. 22: 1100-1104, 1962.

Mycek, M.J. and Nemeth, E.: Microsomal RNA breakdown in livers of phenobarbital-treat ed rats. Biochem. Pharmacol. (In Press).

Mycek, M.J. and Nemeth, E.: Microsomal RNA breakdown in livers of phenobarbital-treated rats. Fed. Proc. 26: 616, 1967.

Nebert, D.W. and Gelboin, H. V/: Drugs and microsomal enzyme formation in vivo and in mammalian cell culture. In Microsomes and Drug Oxidations ed. by J. R. Gillette, A. H. Conney, G. J. Cosmides, R.W. Estabrook, J.R. Fouts, G.J. Mannering, pp 389-429,

Netter, K. J. and Seidel, G.: An adaptively stimulated O-demethylating system in rat liver microsomes and its kinetic properties. J. Pharmacol. Exp. Therap. 146: $61-65,1964$.

O'Malley, B. W.: Hormonal regulation of nucleic acid and protein synthesis. Trans. N. Y. Acad. Sci. (Series II) 31: 478-503, 1969.

Orrenius, S., Das, M. and Gnosspelius, Y.: Overall biochemical effects of drug induction of liver microsomes In Microsomes and Drug Oxidations ed. by J.R. Gillette, A. H. Conney, G. J. Cosmides, R.W. Estabrook, J. R. Foutes, G. J. Mannering, pp. 251-277, Academic Press, New York, 1969. 
Orrenius, S. and Ernster, L.: Phenobarbital-induced synthesis of the oxidative demethylating enzymes of rat liver microsomes. Biochem. Biophys. Res. Commun. 16: 60-65, 1964.

Orrenius, S., Ericsson, J. L.E. and Ernster, L.: Phenobarbital induced synthesis of the microsomal drug metabolizing enzyme system and its relationship to the proliferations of endoplasmic membranes. J. Cell Biol. 25: 627-639, 1965.

Orrenius, S. and Ericsson, J. L.E.: Enzyme-membrane relationship in phenobarbital induction of synthesis of drug metabolizing enzyme system and proliferation of endoplasmic membranes. J. Cell Biol. 28: 181-198,1966.

Perel, J.M., Black, N., Wharton, R.N. and Malitz, S.: Inhibition of imipramine metabolism by methylphenidate. Fed. Proc. 28: 418, 1969.

Philips, F.S., Schwartz, H.S., Sternberg, S.S. and Tan, C. T.C.: The toxicity of actinomycin D. Ann. N.Y. Acad. Sci.: 89: 348-360, 1960.

Rahman, Y.E.: Studies on rat liver ribonucleases I Intracellular localization of the alkaline ribonucleases. Biochim. Biophys. Acta 146: 477-483, 1967.

Recheigl, Jr., M.: In vivo turnover and its role in the metabolic regulation of enzyme levels. Enzymologia 34: 23-39, 1968.

Reich, E., Franklin, R.M., Shaktin, A.J. and Tatum, E.L.: Effect of actinomycin $\mathrm{D}$ on cellular nucleic acid synthesis and virus production. Science 134: 556-557, 1961.

Roth, J.S.: Ribonuclease III Ribonuclease activity in rat liver and kidney. J. Biol. Chem. 208: 181-194, 1954.

Roth, J.S.: Ribonuclease IX.Further Studies on ribonuclease inhibitor. Biochim. Biophys Acta 61: 903-915, 1962.

Rubin, A., Tephly, T.R. and Mannering, G.J.: Kinetics of drug metabolism by hepatic microsomes. Biochem. Pharnacol. 13: 1007-1016, 1964.

Rushton, R. and Steinberg, H.: Dose-response relations of amphetamine barbiturate mixtures. Nature 197: 1017-1018, 1963.

Russell, D. H. and Snyder, S.H.: Amine synthesis in regenerating liver, extremely rapid tumover of ornithine decarboxylase. Mol. Pharmacol. 5: 253-262, 1969. 
Sarkar, N.K.: Mechanism of hormone action. The effect of synthetic corticosteroids on liver RNA and hepatic ribonuclease and ribonuclcase inhibitor activities in rats. FEBS Letters 4: 37-41, 1969.

Scheinbuks, J., Oppenheim, J. and Marcus, L.: A cell-free aminoacid incorporating system from azotobacter vinelandi. Archs Biochem. Biophys. 129: 228-241, 1969 .

Schenkman, J. B.: Meetings: Hepatic microsomal mixed function oxidase. Science 168: 612-613, 1970.

Schenkamn, J. B., Frey, I., Remmer, H. and Estabrook, R. W.: Sex differences in drug metabolism by rat liver microsomes. Mol. Pharmacol. 3: 516-525, 1967.

Schlager, R., Hoffmann, D. and Hilz, H.: Polyribosomes in tumor cells during induction of ribonuclease during cytostatic treatment. Hoppe-Seyler's Z. Physiol. Chem. 350: 1017-1022, 1969.

Schimke, R.T., Ganschow, R., Doyle, D. and Arias, I. M.: Regulation of protein turnover in mammalian tissues. Fed. Proc. 27: 1223-1230, 1968.

Shortman, K.: Studies on cellular inhibitors of ribonuclease I. The assay of the ribonuclease-inhibitor system and the purification of the inhibitor from rat liver. Biochim. Biophys. Acta 51: 37-49, 1961.

Shortman, K.: Studies on cellular inhibitors of ribonuclease III. The levels of ribonucleases and ribonuclease inhibitor during the regeneration of rat liver. Biochim. Biophys. Acta 61: 50-55, 1962a.

Shortman, K.: Studies on cellular inhibitors of ribonuclease II. Some properties of the inhibitor from rat liver. Biochim. Biophys. Acta 55: 88-96, 1962b.

Shuster, L. and Jick, H.: The turnover of microsomal protein in the livers of phenobarbital-treated mice. J. Biol. Chem. 241: 5361-5365, 1966.

Siler, J. G. and Fried, M.: Nuclease activity in cell-free aminoacid-incorporating systems from chicken liver. Biochem. J. 109: 185-190, 1968.

Sladek, N.E., and Mannering, G.J.: Induction of drug metaiolism I. Differences in the mechanisms by which polycyclic hycirocarbons and phenobarbital product their inductive effects on microsomal $\mathrm{N}$-demethylating systems. Mol. Pharmacol. 5: 174-185, 1969. 
Spiegel, M.R. : In Theory and Problems in Statistics, p220, Schaum Publishing Co., New York, 1961.

Steele, W. J.: Phenobarbital-induced prolongation of the half-life of ribosomal RNA of rat liver. Fed. Proc. 29: 737 abs., 1970.

Stein, Y. and Stein, O.: Effect of phenobarbital on rat liver acyl-phosphohydrolases. Israel, J. Med. Sci. 5: 985-990, 1969.

Stone, D. and Joshi, S.: Some evidence for a pathway of amino acid incorporation into rat liver microsomes which does not require transfer ribonucleic acid. Biochim. Biophys. Acta 55: 335-345, 1962.

Street, J. C., Chadwick, R.W., Wang, M. and Philips, R. L.: Insecticide interactions affecting residue storage in animal tissues. J. Agr. Food. Chem. 14: 545-549, 1966.

Talalay, P., Fishman, W. H., and Huggins, C.: Chromogenic substrates II Phenolphtalein glucuronic acid as a substrate for the assay of glucuronidase activity. J. Biol. Chem. 166: 757-772, 1946.

Terner, J.Y., Goodman, R.M. and Spiro, D.: The effect of cortisone on ribonucleic acid polymerase and ribonuclease during development: Coincidental evidence for the identity of ribonucleic acid polymerase with the "operator" gene. Eptl. Cell Res. 45: 550-558, 1967.

Tomkins, G. M., Gelehrter, T. D., Grannaer, D. Martin, Jr., D., Samuels, H. H. , and Thompson, E.B. : Control of specific gene expression in higher organisms. Science 166: 1474-1480, 1969.

Tsukada, K.: Activity of serum ribonuclease after partial hepatectomy and acute stress in the rat. Biochem. Biophy's. Acta 186: 21-24, 1969.

Tsukada, K. and Lieberman, I.: Protein synthesis by liver polyribosomes after partial hepatectomy. Biochem. Biophys. Res. Commun. 19: 702-707, 1965.

Utsunomiya, T. and Roth, J.S.: Studies on the function of intracellular ribonucleases I. Ribonuclease activity in ribosomes and polysomes prepared from rat liver and hepatornas. J. Cell. Biol. 29: 395-403, 1966.

Villabos, J. G., Steele, W. J. and Busch, H.: Increased ribonuclease activity of nuclei of liver cells of thioacetamide-treated rats. Biochem. Biophys. Res. Commun. 17: 723-729, 1964. 
Villabos, J. G., Steele, W. J. and Busch, H.: Ribonuclease activity of isolated nucleoli of livers of thioacetamide-treated rats. Biochim. Biophys. Acta. 103: 195-200, 1965.

Weiss, B. and Laties, V.G.: Effects of amphetamine, chlorpromazine, pentobarbital and ethanol on operant response duration. J. Pharmacol. Exp. Therap . 144: 17-23, 1964.

Wilson, R. G., Wortham, J.S. and Gelboin, H. V.: The effect of phenobarbital and aflatoxin on RNA polymerase of rat liver. Adv. Enzyme Reg. 5: 385-895, 1967. 
Robert T. Louis-Ferdinand was born in New York City on August 3, 1937, where he received his preliminary high school and college education. Following his graduation from college he served in the special service corps of the U. S. Army as a medical laboratory specialist with the Medical Research Laboratories, Ft. Knox, Kentucky and the Research Institute of Environmental Medicine, Natick, Massachusetts. Upon his separation from active duty, he accepted a position as a research biochemist at the Research Institute of Environmental Medicine until September, 1966, when he began full time graduate studies at the University of Rhode Island. He is married to the former Camille Pugliese of New York City. They have four children, Joseph, Genevieve, Amelia and Robert Jr. . He is a member of Rho Chi, Phi Sigma, Sigma Xi and the American Association for the Advancement of Science. Mr. Louis-Ferdinand has accepted a position as an Assistant Professor of Pharmacology and Toxicology at the University of Maryland, Baltimore, Maryland. 